\title{
Hydrogen isotope fractionation in the photolysis of formaldehyde
}

\author{
T. S. Rhee ${ }^{1}$, C. A. M. Brenninkmeijer ${ }^{2}$, and T. Röckmann ${ }^{3}$ \\ ${ }^{1}$ Korea Polar Research Institute, Incheon, Korea \\ ${ }^{2}$ Atmospheric Chemistry Division, Max Planck Institute for Chemistry, Mainz, Germany \\ ${ }^{3}$ Institute for Marine and Atmospheric Research Utrecht, Utrecht University, Utrecht, The Netherlands
}

Received: 2 August 2007 - Published in Atmos. Chem. Phys. Discuss.: 29 August 2007

Revised: 31 January 2008 - Accepted: 1 February 2008 - Published: 7 March 2008

\begin{abstract}
Experiments investigating the isotopic fractionation in the formation of $\mathrm{H}_{2}$ by the photolysis of $\mathrm{CH}_{2} \mathrm{O}$ under tropospheric conditions are reported and discussed. The deuterium (D) depletion in the $\mathrm{H}_{2}$ produced is $500( \pm 20) \%$ o with respect to the parent $\mathrm{CH}_{2} \mathrm{O}$. We also observed that complete photolysis of $\mathrm{CH}_{2} \mathrm{O}$ under atmospheric conditions produces $\mathrm{H}_{2}$ that has virtually the same isotope ratio as that of the parent $\mathrm{CH}_{2} \mathrm{O}$. These findings imply that there must be a very strong concomitant isotopic enrichment in the radical channel $\left(\mathrm{CH}_{2} \mathrm{O}+h v \rightarrow \mathrm{CHO}+\mathrm{H}\right)$ as compared to the molecular channel $\left(\mathrm{CH}_{2} \mathrm{O}+h v \rightarrow \mathrm{H}_{2}+\mathrm{CO}\right)$ of the photolysis of $\mathrm{CH}_{2} \mathrm{O}$ in order to balance the relatively small isotopic fractionation in the competing reaction of $\mathrm{CH}_{2} \mathrm{O}$ with $\mathrm{OH}$. Using a 1-box photochemistry model we calculated the isotopic fractionation factor for the radical channel to be $0.22( \pm 0.08)$, which is equivalent to a $780( \pm 80) \%$ o enrichment in $\mathrm{D}$ of the remaining $\mathrm{CH}_{2} \mathrm{O}$. When $\mathrm{CH}_{2} \mathrm{O}$ is in photochemical steady state, the isotope ratio of the $\mathrm{H}_{2}$ produced is determined not only by the isotopic fractionation occurring during the photolytical production of $\mathrm{H}_{2}\left(\alpha_{m}\right)$ but also by overall fractionation for the removal processes of $\mathrm{CH}_{2} \mathrm{O}\left(\alpha_{f}\right)$, and is represented by the ratio of $\alpha_{m} / \alpha_{f}$. Applying the isotopic fractionation factors relevant to $\mathrm{CH}_{2} \mathrm{O}$ photolysis obtained in the present study to the troposphere, the ratio of $\alpha_{m} / \alpha_{f}$ varies from $\sim 0.8$ to $\sim 1.2$ depending on the fraction of $\mathrm{CH}_{2} \mathrm{O}$ that reacts with $\mathrm{OH}$ and that produces $\mathrm{H}_{2}$. This range of $\alpha_{m} / \alpha_{f}$ can render the $\mathrm{H}_{2}$ produced from the photochemical oxidation of $\mathrm{CH}_{4}$ to be enriched in $\mathrm{D}$ (with respect to the original $\mathrm{CH}_{4}$ ) by the factor of 1.2-1.3 as anticipated in the literature.
\end{abstract}

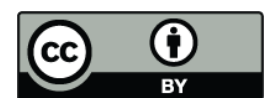

Correspondence to: T. S. Rhee (rhee@kopri.re.kr)

\section{Introduction}

Formaldehyde $\left(\mathrm{CH}_{2} \mathrm{O}\right)$ is a key carbonyl compound in the atmosphere. Its abundance varies over a wide range from subppb levels to $\sim 100 \mathrm{ppb}$ depending largely on local sources (Warneck, 1999). Its turnover is large in the atmosphere and it is a source of molecular hydrogen $\left(\mathrm{H}_{2}\right)$, carbon monoxide $(\mathrm{CO})$, and of the hydroperoxyl radical $\left(\mathrm{HO}_{2}\right)$, yet limited measurements are available in various atmospheric regions. Recent satellite observations of $\mathrm{CH}_{2} \mathrm{O}$ make it possible to investigate its distribution on regional and global scales (e.g., Martin et al., 2004; Wittrock et al., 2006). While direct emissions from fossil fuel combustion, biomass burning, and also automotive exhaust contribute significantly to the burden of atmospheric $\mathrm{CH}_{2} \mathrm{O}$ (Carlier et al., 1986; Garcia et al., 2005), in situ production of $\mathrm{CH}_{2} \mathrm{O}$ by photochemical oxidation of volatile organic compounds appears to be the dominant source on a global scale (Carlier et al., 1986; Warneck, 1999). In remote oceanic areas (Wagner et al., 2002; Weller et al., 2000), in the free troposphere (Frost et al., 2002), and in the stratosphere, only the photochemical oxidation of $\mathrm{CH}_{4}$ serves as the major source. Apart from the importance of the rather simple $\mathrm{CH}_{2} \mathrm{O}$ molecule in the Earth's atmosphere and far beyond, it is also subject to fundamental research regarding for instance the exact processes during its photolysis (e.g., Moore and Weisshaar, 1983; Townsend et al., 2004; Troe, 2007).

$\mathrm{CH}_{2} \mathrm{O}$ is broken down by photolysis ( $\mathrm{R} 1$ and $\mathrm{R} 2$ ) and by photochemical oxidation (R3) in the troposphere (Calvert, 1980):

$$
\begin{aligned}
& \mathrm{CH}_{2} \mathrm{O}+h v \rightarrow \mathrm{CHO}+\mathrm{H} \\
& \mathrm{CH}_{2} \mathrm{O}+h v \rightarrow \mathrm{CO}+\mathrm{H}_{2} \\
& \mathrm{CH}_{2} \mathrm{O}+\mathrm{OH} \rightarrow \mathrm{CHO}+\mathrm{H}_{2} \mathrm{O}
\end{aligned}
$$

Published by Copernicus Publications on behalf of the European Geosciences Union. 
Reaction (R1) produces the $\mathrm{HO}_{2}$ radical by the rapid reaction of hydrogen $(\mathrm{H})$ and formyl $(\mathrm{CHO})$ radicals with atmospheric oxygen $\left(\mathrm{O}_{2}\right)$, which can lead to the formation of the hydroxyl radical $(\mathrm{OH})$ via the reaction with $\mathrm{NO}$ or $\mathrm{O}_{3}$ in the atmosphere. This is an important propagation of the radical chain. Only reaction (R2) yields $\mathrm{H}_{2}$. All photochemical reactions of $\mathrm{CH}_{2} \mathrm{O}$ do produce $\mathrm{CO}$, while solely reaction (R2) forms $\mathrm{H}_{2}$, which is the topic of our research. In fact, this photochemically produced $\mathrm{H}_{2}$ constitutes $\sim 50$ to $\sim 60 \%$ of the total source of tropospheric $\mathrm{H}_{2}$ (Novelli et al., 1999; Rhee et al., 2006b).

In the stratosphere, $\mathrm{H}_{2}$ originates both from this in situ photolysis process (R2), albeit under photochemically very different conditions, and from tropospheric import. Recently it has been established that stratospheric $\mathrm{H}_{2}$ is enriched in deuterium (D) along with the decrease of $\mathrm{CH}_{4}$ mixing ratios whilst the $\mathrm{H}_{2}$ mixing ratios remain almost constant (Rahn et al., 2003; Rhee et al., 2006a; Röckmann et al., 2003). It appears that the $\mathrm{D}$ enrichment of $\mathrm{H}_{2}$ is much stronger than the concomitant enrichment for $\mathrm{CH}_{4}$ acompanying its destruction by $\mathrm{OH}, \mathrm{O}\left({ }^{1} \mathrm{D}\right)$, and $\mathrm{Cl}$ radicals. This means that the D enrichment of $\mathrm{H}_{2}$ occurs not only by the fractionation in the reaction of $\mathrm{H}_{2}$ with oxidizing radicals $\left(\mathrm{OH}, \mathrm{Cl}, \mathrm{O}\left({ }^{1} \mathrm{D}\right)\right)$ but is also due to the chain reactions leading from $\mathrm{CH}_{4}$ to $\mathrm{H}_{2}$ (Rhee et al., 2006a). Gerst and Quay (2001) discussed potential reactions that may lead to the $\mathrm{D}$ enrichment along the photochemical chain reactions of $\mathrm{CH}_{4}$. However, the detailed mechanism by which the $\mathrm{D}$ content of $\mathrm{H}_{2}$ is accumulated has not yet been elucidated due to the lack of measurements for isotopic fractionation factors at each reaction step and branching, all of which are fundamentally difficult to determine.

To address this question, as a first step we have investigated the isotopic fractionation occurring during the photolysis of $\mathrm{CH}_{2} \mathrm{O}$ by which $\mathrm{H}_{2}$ is produced for the conditions at Earth's surface. In spite of its crucial role in the isotope budget of $\mathrm{H}_{2}$, as well as $\mathrm{CO}$, in the atmosphere, the isotopic fractionation occurring during photolysis of $\mathrm{CH}_{2} \mathrm{O}$ has been rarely investigated in the past (Crounse et al., 2003; Feilberg et al., 2005; Feilberg et al., 2007b). Since $\mathrm{CH}_{2} \mathrm{O}$ is a relatively "long-lived" intermediate in the photochemical chain reactions between $\mathrm{CH}_{4}$ and $\mathrm{H}_{2}$, the results will provide essential insight into understanding the accumulation of $\mathrm{D}$ in $\mathrm{H}_{2}$ produced.

\section{Experiments}

Formaldehyde $\left(\mathrm{CH}_{2} \mathrm{O}\right)$ was prepared by purifying paraformaldehyde (Merck) in a vacuum system following the method of Spence and Wild (1935). Solid paraformaldehyde was heated at $\sim 420 \mathrm{~K}$ under vacuum. For purification the evaporating $\mathrm{CH}_{2} \mathrm{O}$ and impurities were forced through a set of glass U-tubes which were partly immersed in an ethanol sludge $(\sim 160 \mathrm{~K})$ made with liquid nitrogen. $\mathrm{Pu}-$ rified formaldehyde was then collected in a U-tube dipped in liquid nitrogen $(77 \mathrm{~K})$. A given amount of pure $\mathrm{CH}_{2} \mathrm{O}$ ( $\sim 3$ mbar) was released to a 3-L glass bulb and several 0.1-L glass flasks simultaneously, all of which were connected to the same manifold. The pure $\mathrm{CH}_{2} \mathrm{O}$ in the $0.1-\mathrm{L}$ glass flasks were used to determine the $\mathrm{D} / \mathrm{H}$ ratio of the $\mathrm{CH}_{2} \mathrm{O}$ (see below). Afterwards pressure inside the manifold was read by a capacitance manometer (MKS10, Baratron). $\mathrm{CH}_{2} \mathrm{O}$-free synthetic air was then introduced into the 3-L glass bulb to reach about ambient pressure and the final pressure was read by another capacitance manometer (MKS1000, Baratron) to determine the $\mathrm{CH}_{2} \mathrm{O}$ mixing ratio. Since these pressure readings are essential for determining the $\mathrm{CH}_{2} \mathrm{O}$ mixing ratio in the reactors used for the photolysis experiments, the capacitance manometers were calibrated accurately by an absolute manometer (Digiquartz 740, Paroscientific) whenever necessary. The $\mathrm{CH}_{2} \mathrm{O}$-air mixture was used as a stock for a series of $\mathrm{CH}_{2} \mathrm{O}$ photolysis experiments. The $\mathrm{CH}_{2} \mathrm{O}$ mixing ratios in the stock air were usually around $0.3 \%$.

Aliquots of the $\mathrm{CH}_{2} \mathrm{O}$ stock air were transferred to quartz or glass flasks, diluted to the target mixing ratio with $\mathrm{CH}_{2} \mathrm{O}-$ free synthetic air, and photolyzed for a few hours to $\sim 17$ days (Table 1). The $\mathrm{CH}_{2} \mathrm{O}$ mixing ratios in the reactors were less than $\sim 2 \mathrm{ppm}$ except in the experiments running for few hours, for which $\sim 50 \mathrm{ppm}$ of $\mathrm{CH}_{2} \mathrm{O}$ was used. After photolysis we measured the $\mathrm{H}_{2}$ mixing ratio and $\mathrm{D} / \mathrm{H}$ ratio. The $\delta \mathrm{D}$ values and mixing ratios of the $\mathrm{H}_{2}$ produced were determined by a recently developed technique involving continuous-flow isotope ratio mass spectrometry (Rhee et al., 2004).

In order to test stability of $\mathrm{CH}_{2} \mathrm{O}$ in the reactor, we had once monitored the pressure inside the 3-L glass bulb for 2 days after injecting pure $\mathrm{CH}_{2} \mathrm{O}$ at $\sim 3$ mbar. No change in pressure inside was found, indicating no absorption or loss of $\mathrm{CH}_{2} \mathrm{O}$ by polymerization or heterogeneous reactions. The same results even at higher pressure of pure $\mathrm{CH}_{2} \mathrm{O}$ air have been reported (e.g.,Horowitz and Calvert, 1978).

All glass used was Duran glass (Schott), thoroughly evacuated and heated prior to use. Glass bulbs were kept in the dark by wrapping them with aluminum foil or with black cloth to avoid any photochemical reactions prior to commencing $\mathrm{CH}_{2} \mathrm{O}$ photolysis experiments. $\mathrm{CH}_{2} \mathrm{O}$ photolysis experiments in sunlight were carried out on the roof of a 3 -story building of the Max Planck Institute for Chemistry, Mainz $\left(50^{\circ} \mathrm{N}, 8.16^{\circ} \mathrm{E}\right)$, in August and September of 2003 and in March, May and June of 2004 (Table 1). We also conducted $\mathrm{CH}_{2} \mathrm{O}$ photolysis experiments using a xenon (Xe) short arc lamp (XBO 75W/2). A characteristic intensity spectrum of the light sources and the transmission of the reactor materials are shown in Fig. 1 together with photolytic properties of $\mathrm{CH}_{2} \mathrm{O}$.

The $\mathrm{D} / \mathrm{H}$ ratio of the original $\mathrm{CH}_{2} \mathrm{O}$ in the stock air was determined by analyzing the isotopic composition of the pure $\mathrm{CH}_{2} \mathrm{O}$ in the 0.1-L glass flasks, which originated from the same source of $\mathrm{CH}_{2} \mathrm{O}$ as that in the stock air (see above). The pure $\mathrm{CH}_{2} \mathrm{O}$ sample was photolyzed using a mercury 
Table 1. Summary of $\mathrm{CH}_{2} \mathrm{O}$ photolysis experiments.

\begin{tabular}{|c|c|c|c|c|c|c|c|}
\hline \multicolumn{3}{|c|}{ Photolysis } & \multirow{2}{*}{$* *\left[\mathrm{CH}_{2} \mathrm{O}\right]_{0}(\mathrm{ppm})$} & \multirow{2}{*}{ Light source } & \multirow{2}{*}{ Reactor material } & \multirow{2}{*}{$\Psi\left(\mathrm{H}_{2}\right)$} & \multirow{2}{*}{$\delta \mathrm{D}-\mathrm{H}_{2}(\% o)$} \\
\hline Start & End & *Duration (h) & & & & & \\
\hline 4-Sep-03 & 10-Sep-03 & 91 & 2.3 & Daylight & Glass & 0.47 & -247 \\
\hline 4-Sep-03 & $10-$ Sep-03 & 91 & 2.5 & Daylight & Glass & 0.52 & -190 \\
\hline 4-Sep-03 & 10-Sep-03 & 91 & 2.6 & Daylight & Glass & 0.49 & -252 \\
\hline 14-Sep-03 & $17-$ Sep-03 & 51 & 0.43 & Daylight & Glass & 0.52 & -214 \\
\hline 14-Sep-03 & $17-$ Sep-03 & 51 & 0.46 & Daylight & Glass & 0.66 & -46 \\
\hline $14-S e p-03$ & $17-$ Sep-03 & 51 & 0.48 & Daylight & Glass & 0.56 & -205 \\
\hline 29-Mar-04 & 29-Mar-04 & 1 & 53 & Daylight & Quartz & 0.09 & -449 \\
\hline 29-Mar-04 & 29-Mar-04 & 2 & 50 & Daylight & Quartz & 0.18 & -459 \\
\hline 29-Mar-04 & 29-Mar-04 & 3 & 34 & Daylight & Quartz & 0.21 & -415 \\
\hline 29-Mar-04 & 29-Mar-04 & 7 & 63 & Daylight & Quartz & 0.31 & -366 \\
\hline 29-Mar-04 & 29-Mar-04 & 7 & 36 & Daylight & Quartz & 0.26 & -413 \\
\hline 17-Мау-04 & 25-Маy-04 & 130 & 2.1 & Daylight & Quartz & 0.67 & 3 \\
\hline 17-May-04 & 31-May-04 & 230 & 2.0 & Daylight & Quartz & 0.68 & -4 \\
\hline 14-Jun-04 & 18-Jun-04 & 67 & 1.4 & Daylight & Quartz & 0.50 & -205 \\
\hline 14-Jun-04 & 18-Jun-04 & 67 & 1.8 & Daylight & Quartz & 0.61 & -38 \\
\hline 14-Jun-04 & 18-Jun-04 & 67 & 1.8 & Daylight & Quartz & 0.61 & -77 \\
\hline 14-Jun-04 & 18-Jun-04 & 67 & 1.1 & Daylight & Quartz & 0.39 & -256 \\
\hline 14-Jun-04 & 30-Jun-04 & 277 & 2.1 & Daylight & Quartz & 0.71 & 15 \\
\hline 14-Jun-04 & 30-Jun-04 & 277 & 1.9 & Daylight & Quartz & 0.66 & -65 \\
\hline 30-May-04 & 4-Jun-04 & 80 & 1.6 & Daylight & Glass & 0.56 & -137 \\
\hline 30-May-04 & 4-Jun-04 & 80 & 1.6 & Daylight & Glass & 0.60 & -113 \\
\hline 5-Jun-04 & 11-Jun-04 & 94 & 1.6 & Daylight & Glass & 0.54 & -132 \\
\hline \multirow[t]{8}{*}{ 5-Jun-04 } & 11-Jun-04 & 94 & 1.5 & Daylight & Glass & 0.59 & -78 \\
\hline & & 92 & 1.5 & Xe arc lamp & Quartz & 0.44 & -12 \\
\hline & & 244 & 1.4 & Xe arc lamp & Quartz & 0.43 & 5 \\
\hline & & 10 & 3 mbar & $\mathrm{Hg}$ arc Lamp & Quartz & 0.98 & 7 \\
\hline & & 10 & $3 \mathrm{mbar}$ & $\mathrm{Hg}$ arc Lamp & Quartz & 0.97 & -8 \\
\hline & & 13 & $3 \mathrm{mbar}$ & $\mathrm{Hg}$ arc Lamp & Quartz & 1.00 & 1 \\
\hline & & 13 & 3.3 mbar & $\mathrm{Hg}$ arc Lamp & Quartz & 0.95 & 0 \\
\hline & & 12 & 3.3 mbar & $\mathrm{Hg}$ arc Lamp & Quartz & 0.99 & 0 \\
\hline
\end{tabular}

\footnotetext{
* This is simply a sum of daylight hours calculated using astronomical parameters from the internet (http://aa.usno.navy.mil/data/docs/ RS_OneDay.html).

** Initial mixing ratios of $\mathrm{CH}_{2} \mathrm{O}$ in a reactor prior to photolysis. For the photolysis of pure $\mathrm{CH}_{2} \mathrm{O}$, unit of pressure is used.
}

(Hg) short arc lamp (HBO 103W/2, OSRAM). The photolysis of pure $\mathrm{CH}_{2} \mathrm{O}$ produces not only $\mathrm{CO}$ and $\mathrm{H}_{2}$ but also $\mathrm{H}$ and $\mathrm{CHO}$ radicals which further undergo self reactions and reaction with $\mathrm{CH}_{2} \mathrm{O}$, ending up with the production of $\mathrm{CO}$ and $\mathrm{H}_{2}$ (e.g., Calvert, 1980). Thus, the final products of the photolysis are only $\mathrm{CO}$ and $\mathrm{H}_{2}$. Isotopic mass balance requires that for complete conversion the product $\mathrm{H}_{2}$ has the same isotopic composition as the parent $\mathrm{CH}_{2} \mathrm{O}$. Complete conversion of the $\mathrm{CH}_{2} \mathrm{O}$ to $\mathrm{CO}$ and $\mathrm{H}_{2}$ was confirmed by measuring the amount of $\mathrm{H}_{2}$ produced and its isotopic composition. The deuterium content is as usual expressed as $\delta \mathrm{D}=\left(\mathrm{R}_{\mathrm{SPL}} / \mathrm{R}_{\mathrm{STD}}-1\right) \times 1000(\%)$, where $\mathrm{R}_{\mathrm{SPL}}$ and $\mathrm{R}_{\mathrm{STD}}$ represent the $\mathrm{D} / \mathrm{H}$ of $\mathrm{H}_{2}$ for sample and a reference material, respectively. For convenience, we express the $\delta \mathrm{D}$ values relative to the isotopic composition of the parent $\mathrm{CH}_{2} \mathrm{O}$.

\section{Results}

\subsection{The yield of $\mathrm{H}_{2}$ in the photolysis of $\mathrm{CH}_{2} \mathrm{O}$}

As mentioned earlier, photolysis of $\mathrm{CH}_{2} \mathrm{O}$ has one channel that produces $\mathrm{CHO}$ and $\mathrm{H}$ radicals $(\mathrm{R} 1)$ and the other that produces $\mathrm{CO}$ and $\mathrm{H}_{2}$ molecules (R2). The $\mathrm{CHO}$ radical reacts rapidly with $\mathrm{O}_{2}$ in the air, also forming $\mathrm{CO}$. Thus, the amount of $\mathrm{CO}$ produced should always be the same as that of $\mathrm{CH}_{2} \mathrm{O}$ photolyzed, while the amount of $\mathrm{H}_{2}$ produced represents the fraction of $\mathrm{CH}_{2} \mathrm{O}$ that follows the molecular channel (R2). Thereby, the yield of the molecular channel in the photolysis of $\mathrm{CH}_{2} \mathrm{O}$, given as $\Phi\left(\mathrm{H}_{2}\right)$, can be defined by the ratio of $\mathrm{H}_{2}$ to $\mathrm{CO}$.

However, a portion of the $\mathrm{CH}_{2} \mathrm{O}$ in the reactor may react with the radicals, $\mathrm{H}, \mathrm{OH}$, and $\mathrm{HO}_{2}$, as they are produced in the reactor during the photolysis. These reactions produce $\mathrm{CO}$ and formic acid $(\mathrm{HCOOH})$. The reaction of 


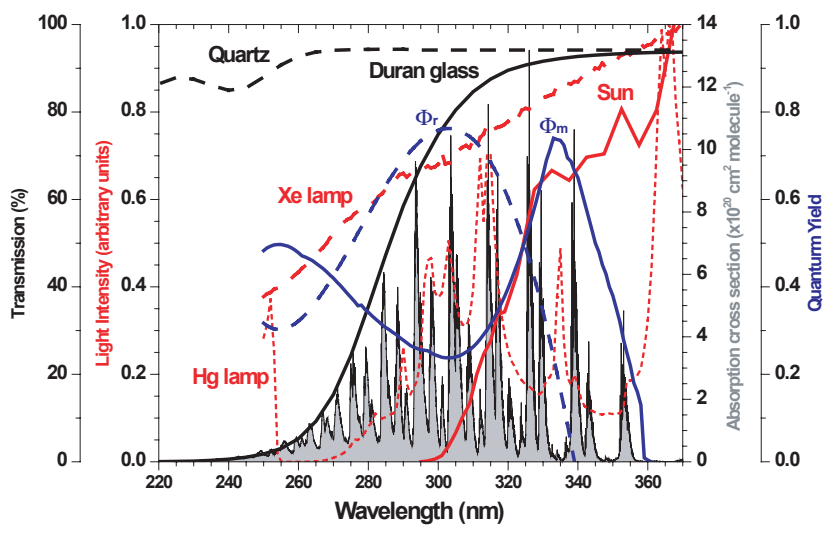

Fig. 1. Absorption cross section (gray shade) (Meller and Moortgat, 2000) and quantum yields (blue lines) (Sander et al., 2006) of $\mathrm{CH}_{2} \mathrm{O}$, light transmission of the reactors, and intensity of the lights used in the experiments. $\Phi_{r}$ and $\Phi_{m}$ indicate the quantum yields of the radical and molecular channels, respectively, in $\mathrm{CH}_{2} \mathrm{O}$ photolysis. Light transmissions of quartz (black dashed line) and Duran glass (Schott) (black solid line) are from a company measurement. Spectra of $\mathrm{Xe}$ (red dashed line) and $\mathrm{Hg}$ (red dotted line) short arc lamps were provided by OSRAM, and normalized actinic flux (red solid line) at the Earth's surface is from Finlayson-Pitts and Pitts (1999).

$\mathrm{CH}_{2} \mathrm{O}$ with $\mathrm{HO}_{2}$ produces the hydroxymethylperoxy radical $\left(\mathrm{HOCH}_{2} \mathrm{OO}\right)$. This radical is so unstable that it immediately dissociates back to $\mathrm{CH}_{2} \mathrm{O}$. However, a fraction reacts with $\mathrm{HO}_{2}$ or itself producing $\mathrm{HCOOH}$ (Burrows et al., 1989; Su et al., 1979; Veyret et al., 1989) (see Sect. 3.2 for details). In addition, $\mathrm{CO}$ and any $\mathrm{HCOOH}$ produced can react further with $\mathrm{OH}$ to form their oxidized products. These reactions may result in a deficit in the mass balance of $\mathrm{CO}$ if only photolysis of $\mathrm{CH}_{2} \mathrm{O}$ is considered. Because of such a non-conservation of $\mathrm{CO}$ in the reactor, we did not attempt to measure the ratio of the mixing ratios of $\mathrm{H}_{2}$ to $\mathrm{CO}$ for each photolysis run to obtain the value of $\Phi\left(\mathrm{H}_{2}\right)$. But, we tracked the actual fraction of $\mathrm{H}_{2}$ produced by photolysis of $\mathrm{CH}_{2} \mathrm{O}$, given as $\Psi\left(\mathrm{H}_{2}\right)$, which represents the ratio of the $\mathrm{H}_{2}$ mixing ratio in the reactor to the initial $\mathrm{CH}_{2} \mathrm{O}$ mixing ratio.

Figure 2 shows the evolution of $\Psi\left(\mathrm{H}_{2}\right)$ throughout the periods of photolysis for experiments conducted with different reactor materials or light sources. The period of photolysis is given as number of daylight hours disregarding any parameters that might influence the actual photolysis rates of $\mathrm{CH}_{2} \mathrm{O}$. For the short periods experiments $(<12 \mathrm{~h}), \Psi\left(\mathrm{H}_{2}\right)$ increases rapidly with the increase of photolysis time. At long periods of photolysis $(>130 \mathrm{~h}), \Psi\left(\mathrm{H}_{2}\right)$ converges toward an asymptotic value. By virtue of negligible production of $\mathrm{H}_{2}$ $\left(<10^{-8}\right.$ per $\mathrm{CH}_{2} \mathrm{O}$ according to the model described below) through reactions other than the $\mathrm{CH}_{2} \mathrm{O}$ photolysis and of little reactivity of $\mathrm{H}_{2}$ in the reactor for the periods of the $\mathrm{CH}_{2} \mathrm{O}$ photolysis, $\Psi\left(\mathrm{H}_{2}\right)$ approaches an asymptotic value as a function of time. This asymptotic value of $\Psi\left(\mathrm{H}_{2}\right)$ is equivalent to $\Phi\left(\mathrm{H}_{2}\right)$ when $\mathrm{CH}_{2} \mathrm{O}$ is destroyed only by photolysis.

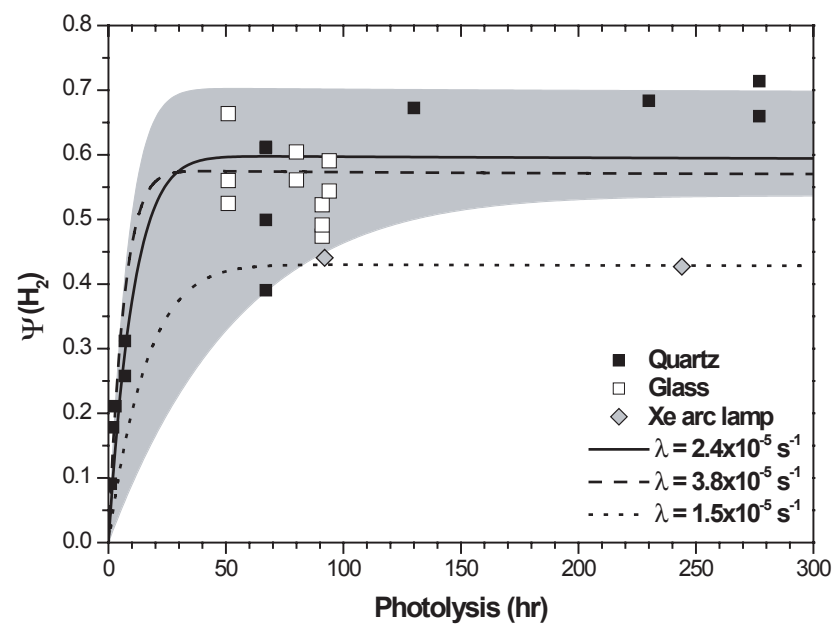

Fig. 2. Evolution of the fraction of $\mathrm{H}_{2}\left(\Psi\left(\mathrm{H}_{2}\right)\right)$ produced by photolysis of $\mathrm{CH}_{2} \mathrm{O}$ in daylight or using a Xe short arc lamp. The gray-shaded area and lines represent model calculations for a given $\mathrm{CH}_{2} \mathrm{O}$ photolysis rate and yield of $\mathrm{H}_{2}, \Phi\left(\mathrm{H}_{2}\right)$. Solid and dashed lines are the bounds of the most probable evolution of $\Psi\left(\mathrm{H}_{2}\right)$ in Mainz using the results from the Tropospheric Ultraviolet and Visible (TUV) radiation model as described in Fig. 3. For photolysis with the Xe lamp, the photolysis rate of $1.5 \times 10^{-5} \mathrm{~s}^{-1}$ and $\Phi\left(\mathrm{H}_{2}\right)=0.49$ are arbitrarily forced to fit the measurements.

For the photolysis periods from 50 to $100 \mathrm{~h}$, the measurements are scattered. We suspect that this is due mostly to photolytical effects rather than analytical errors. In particular, changes in radiation occurring over the course of the experiments on the roof (e.g., cloudiness, albedo, solar zenith angle (SZA), light scattering due to aerosol content, etc.) may result in such different values. In addition, since the quantum yield of the molecular channel peaks at longer wavelengths compared to the radical channel (Moortgat et al., 1983), $\Psi\left(\mathrm{H}_{2}\right)$ increases with the increase of SZA. As an indirect support for this speculation, photolysis of $\mathrm{CH}_{2} \mathrm{O}$ performed in the laboratory using $\mathrm{Hg}$ and Xe short arc lamps shows that the uncertainty of replicate runs is merely about $2 \%$ for the yield of $\mathrm{H}_{2}$. Provided that the scatter is due to variabilities of the parameters that influence photolysis rate of $\mathrm{CH}_{2} \mathrm{O}$, we did not average the values of $\Psi\left(\mathrm{H}_{2}\right)$ for the same period of photolysis, but the individual values were used to determine the isotopic fractionation factors for the $\mathrm{CH}_{2} \mathrm{O}$ photolysis.

The $\mathrm{CH}_{2} \mathrm{O}$ photolysis experiments conducted with a $\mathrm{Xe}$ short arc lamp give an opportunity to qualitatively examine a relation between $\Phi\left(\mathrm{H}_{2}\right)$ and the range of wavelengths by which $\mathrm{CH}_{2} \mathrm{O}$ is photolyzed. As a Xe short arc lamp emits photons within a broad range of wavelengths, the effective wavelength for the photolysis of $\mathrm{CH}_{2} \mathrm{O}$ depends on the cutoff wavelength for transmission through quartz which extends down to $\sim 200 \mathrm{~nm}$ (see Fig. 1). This is shorter than the lower limit of solar wavelengths at the Earth's surface. 

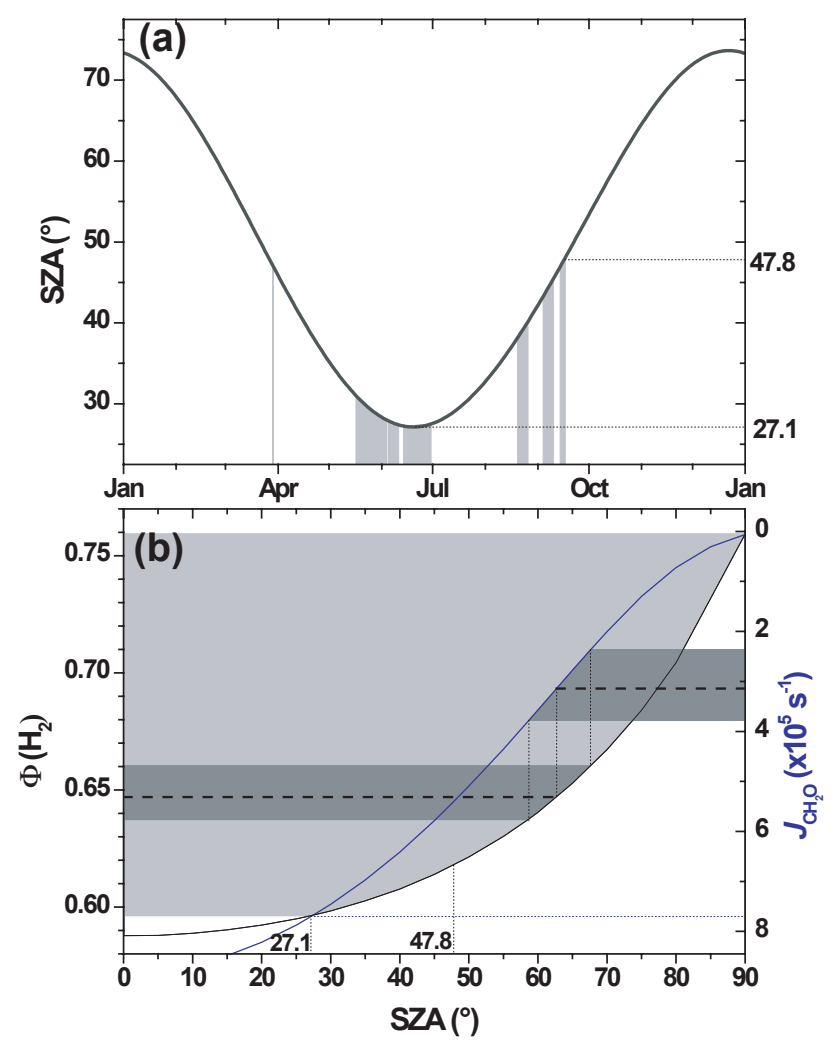

Fig. 3. (a) Solar zenith angle (SZA) at local noon in Mainz (11:00 GMT) in 2004. Gray shaded areas indicate the dates when experiments were conducted. SZA at local noon ranges from $27.1^{\circ}$ to $47.8^{\circ}$ for the periods of experiment. (b) Photolytic yield of $\mathrm{H}_{2}$ $\left(\Phi\left(\mathrm{H}_{2}\right)\right)$ and photolysis rate of $\mathrm{CH}_{2} \mathrm{O}\left(\mathrm{J}_{\mathrm{CH}_{2} \mathrm{O}}\right)$ at a given solar zenith angle calculated with the TUV radiation model. The grayshaded area indicates a range of $\Phi\left(\mathrm{H}_{2}\right)$ for the situation of Mainz, and the blue line represents the photolysis rates at a given SZA. The dark gray area represents daily mean values of $\Phi\left(\mathrm{H}_{2}\right)$ and their corresponding values of $J_{\mathrm{CH}_{2} \mathrm{O}}$ obtained by weighting the photolysis rates over the range of SZA for the experimental periods. The dashed line indicates the arithmetic mean of minimum and maximum values of these mean values of $J_{\mathrm{CH}_{2} \mathrm{O}}$ and its mapping onto values for $\Phi\left(\mathrm{H}_{2}\right)$. These two values of $J_{\mathrm{CH}_{2} \mathrm{O}}$ and $\Phi\left(\mathrm{H}_{2}\right)$ were then used in the 1-box photochemistry model.

Consequently, $\Phi\left(\mathrm{H}_{2}\right)$ from the Xe short arc lamp experiments should be smaller than that obtained with sunlight because of the dominance of the radical channel in $\mathrm{CH}_{2} \mathrm{O}$ photolysis at these short wavelengths (Moortgat et al., 1983). As shown in Fig. 2, $\Psi\left(\mathrm{H}_{2}\right)$ is almost the same for the two different irradiation periods, indicating that it has reached an asymptote. This asymptotic value is smaller than that obtained in sunlight, which, as expected, reflects a smaller value of $\Phi\left(\mathrm{H}_{2}\right)$ using the Xe short arc lamp.

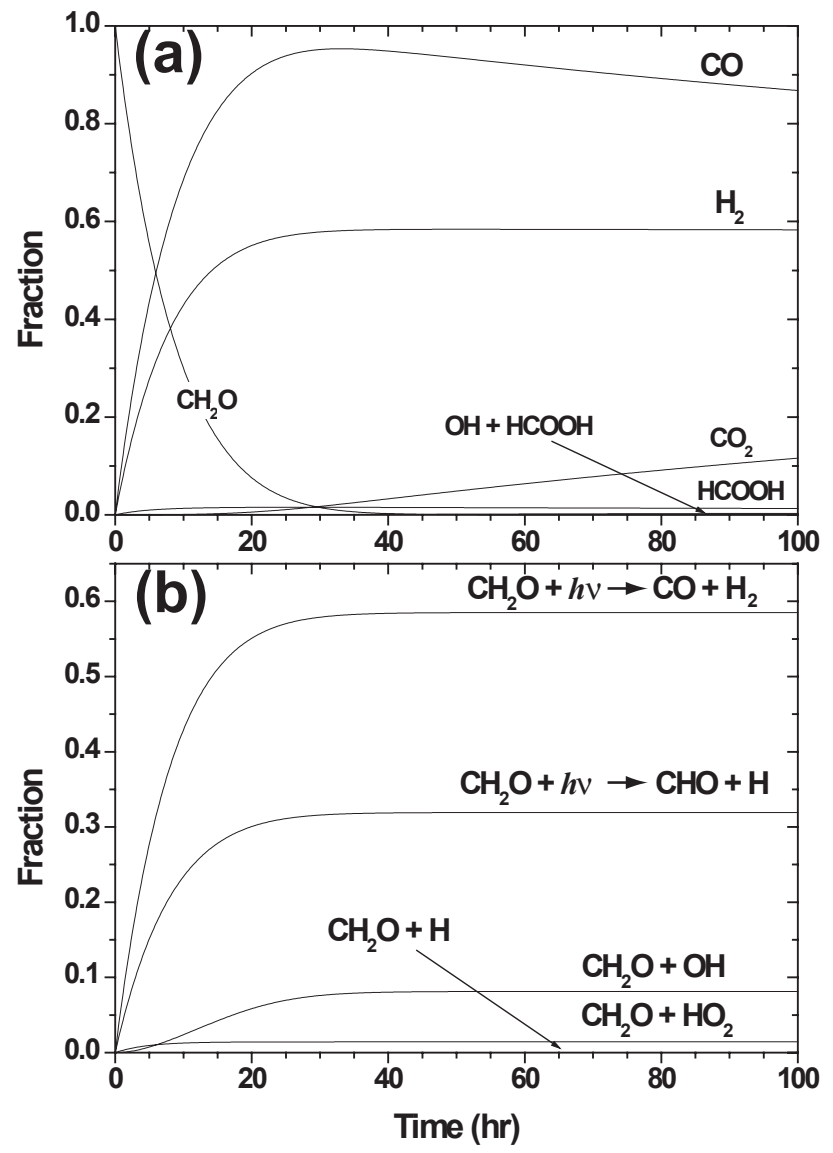

Fig. 4. A 1-box model simulation of $\mathrm{CH}_{2} \mathrm{O}$ photochemistry in the reactor. Details of the reactions are given in Appendix A. (a) Time evolution of the relative abundances of $\mathrm{CH}_{2} \mathrm{O}$ and its photochemical products. "OH+HCOOH" represents the sum of the amounts of any compounds produced by the reaction of formic acid and $\mathrm{OH}$ radical. (b) Time evolution of the fraction of $\mathrm{CH}_{2} \mathrm{O}$ that is photolyzed or reacts with radicals.

\subsection{A box model simulation of $\mathrm{CH}_{2} \mathrm{O}$ photolysis}

To examine the actual photochemistry in the reactor, we constructed a 1-box model composed of 33 photochemical reactions, including photolysis of $\mathrm{CH}_{2} \mathrm{O}$ and $\mathrm{H}_{2} \mathrm{O}_{2}$ as well as formation of $\mathrm{HCOOH}$ (see Appendix A). The model was run under conditions of standard ambient temperature $\left(25^{\circ} \mathrm{C}\right)$ and pressure $\left(10^{5} \mathrm{~Pa}\right)$ with the other boundary conditions from the results from the Tropospheric Ultraviolet and Visible (TUV) radiation model (http://cprm.acd.ucar. edu/Models/TUV). As shown in Fig. 3, the TUV radiation model predicts that the values of $\Phi\left(\mathrm{H}_{2}\right)$ range from 0.6 to 0.76 in Mainz. Since SZA at local noon during the experiments were between $27^{\circ}$ and $48^{\circ}$, daily averaged photolysisrate-weighted mean values of $\Phi\left(\mathrm{H}_{2}\right)$ would be 0.64 to 0.66 , which correspond to total $\mathrm{CH}_{2} \mathrm{O}$ photolysis rates for both channels $\left(J_{\mathrm{CH}_{2} \mathrm{O}}\right)$ of $2.4 \times 10^{-5}$ to $3.8 \times 10^{-5} \mathrm{~s}^{-1}$. For the same range of SZA, the ratio of the photolysis rates of $\mathrm{H}_{2} \mathrm{O}_{2}$ 


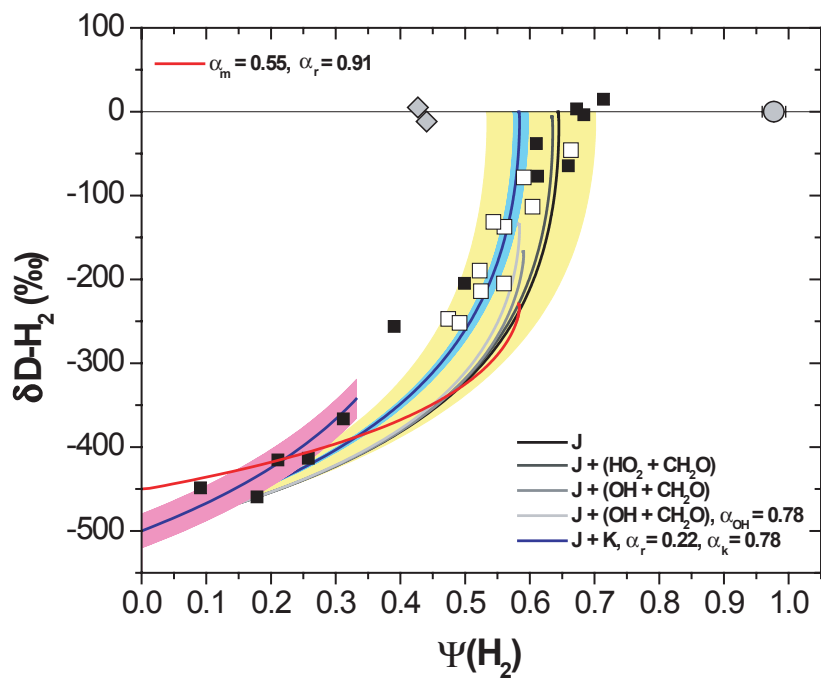

Fig. 5. Evolution of $\delta \mathrm{D}-\mathrm{H}_{2}$ as a function of the fraction of $\mathrm{H}_{2}$ produced by photolysis of $\mathrm{CH}_{2} \mathrm{O}$. Symbol keys are the same as in Fig. 2 except the gray circle designating the mean value for photolysis of pure $\mathrm{CH}_{2} \mathrm{O}$ using a $\mathrm{Hg}$ short arc lamp. Several model sensitivity runs are shown with solid lines. Yellow shading indicates potential isotopic fractionation evolutions for various ranges of $\Phi\left(\mathrm{H}_{2}\right)$ for the location of Mainz, and cyan shading represents the isotopic fractionation evolutions using the daily-mean value of $\Phi\left(\mathrm{H}_{2}\right)$ during the experiments according to the TUV radiation model described in Fig. 3. For the short duration experiments, we assumed that the initial mixing ratio of $\mathrm{CH}_{2} \mathrm{O}$ in the 1-box model was $50 \mathrm{ppm}$, represented by magenta shading. When calculating the evolution of $\delta \mathrm{D}-\mathrm{H}_{2}$ using the 1-box model, we constrain the model such that the values of $\alpha_{m}$ and $\alpha_{K}$ (see text) are always 0.50 and 0.78 , respectively, and that the complete photolysis of $\mathrm{CH}_{2} \mathrm{O}$ yields $\mathrm{H}_{2}$ with a $\delta \mathrm{D}$ value that is the same as that of the initial $\mathrm{CH}_{2} \mathrm{O}$. For comparison, the evolutions of $\delta \mathrm{D}-\mathrm{H}_{2}$ using the isotopic fractionation factors determined by Feilberg et al. (2007b) is shown as red solid line on the premise that the values of other parameters are the same as those in the present study (see Appendix A).

and $\mathrm{CH}_{2} \mathrm{O}, J_{\mathrm{H}_{2} \mathrm{O}_{2}} / J_{\mathrm{CH}_{2} \mathrm{O}}$, varies only from 0.089 to 0.090 . The initial mixing ratio of $\mathrm{CH}_{2} \mathrm{O}$ was assumed to be $1 \mathrm{ppm}$ in synthetic air $\left(78 \%\right.$ of $\mathrm{N}_{2}$ and $22 \%$ of $\mathrm{O}_{2}$ ). The commercial software package FACSIMILE (MCPA Software, UK) was used to integrate time derivatives of the chemical species in the reactions.

As shown in Fig. 4, while photochemical destruction of $\mathrm{CH}_{2} \mathrm{O}$ forms $\mathrm{CO}$ and $\mathrm{HCOOH}$, both of which are further oxidized by reacting with the $\mathrm{OH}$ radical, $\mathrm{H}_{2}$ in the reactor is almost entirely produced by $\mathrm{CH}_{2} \mathrm{O}$ photolysis to the molecular channel (R2) and is little oxidized by the $\mathrm{OH}$ radical within the time periods of the experiments $\left(<0.1 \%\right.$ of $\mathrm{H}_{2}$ has reacted at $99 \%$ of $\mathrm{CH}_{2} \mathrm{O}$ being oxidized). Hence, a substantial portion of the initial $\mathrm{CH}_{2} \mathrm{O}$ is converted to products other than $\mathrm{CO}$, but the $\mathrm{H}_{2}$ produced is accumulated in the reactor reaching an asymptotic value at full conversion.
The time evolutions of $\Psi\left(\mathrm{H}_{2}\right)$ were predicted by applying the values of $\Phi\left(\mathrm{H}_{2}\right), J_{\mathrm{CH}_{2} \mathrm{O}}$, and $J_{\mathrm{H}_{2} \mathrm{O}_{2}}$ from the TUV radiation model described above to the 1-box model (Fig. 2). The results appear comparable to the measurements for photolysis periods of $<12 \mathrm{~h}$. However, there are substantial differences between the measurements and the model predictions at longer photolysis periods. In particular, the asymptotic value of the measurements differs from the model predictions when the most likely values of parameters under photochemical conditions in Mainz, Germany, are applied (solid and dashed lines in Fig. 2). As shown in Fig. 4 b, $\sim 10 \%$ of $\mathrm{CH}_{2} \mathrm{O}$ is destroyed by the reactions with radicals. This leads to the lower asymptotes of $\Psi\left(\mathrm{H}_{2}\right)$ than the value of $\Phi\left(\mathrm{H}_{2}\right)$ obtained from the TUV radiation model because this asymptotic value of $\Psi\left(\mathrm{H}_{2}\right)$ is smaller than $\Phi\left(\mathrm{H}_{2}\right)$ by a factor corresponding to the fraction of $\mathrm{CH}_{2} \mathrm{O}$ photolyzed. In order to reproduce the asymptote of $\Psi\left(\mathrm{H}_{2}\right)$ from the measurements in the model, a value of $\Phi\left(\mathrm{H}_{2}\right) \approx 0.74$ is necessary, the value that the TUV radiation model predicts when SZA is near $85^{\circ}$ in the location of Mainz. This SZA is larger than the weighted-mean value of $63^{\circ}$ predicted by the model. This discrepancy could be associated with feeding the parameters relevant to photochemical reactions in the model without accounting for their variation along the change in radiation as mentioned above.

\subsection{Isotope effect of the $\mathrm{CH}_{2} \mathrm{O}$ photolysis to the molecular channel}

Figure 5 shows the variation of the $\delta \mathrm{D}$ value of $\mathrm{H}_{2}(\delta \mathrm{D}$ $\mathrm{H}_{2}$ ) as a function of $\Psi\left(\mathrm{H}_{2}\right)$. As the isotope ratios are normalized with respect to the $\delta \mathrm{D}$ value of the initial $\mathrm{CH}_{2} \mathrm{O}$, a $\delta \mathrm{D}-\mathrm{H}_{2}$ value of zero means that the isotope ratio of the $\mathrm{H}_{2}$ in sample air is the same as that for the initial $\mathrm{CH}_{2} \mathrm{O}$. The air samples whose values of $\Psi\left(\mathrm{H}_{2}\right)$ approach the asymptotic values at long photolysis times for both the sunlight and $\mathrm{Xe}$ short arc lamp experiments show near-zero values of $\delta \mathrm{D}-\mathrm{H}_{2}$. This indicates that complete photochemical decomposition of $\mathrm{CH}_{2} \mathrm{O}$ yields $\mathrm{H}_{2}$ that has the same isotope ratios as the initial $\mathrm{CH}_{2} \mathrm{O}$. This observation and the evolution of $\delta \mathrm{D}-\mathrm{H}_{2}$ as a function of $\Psi\left(\mathrm{H}_{2}\right)$ give us crucial information to aid in determining the hydrogen isotopic fractionation processes occurring in (R1) and (R2) as follows.

According to the results from the 1-box model described in Sect. 3.2, most of the $\mathrm{CH}_{2} \mathrm{O}$ in the reactor is broken down by photolysis $(>90 \%)$ with the remainder being destroyed mostly by reaction with $\mathrm{OH}(<8 \%)$ while $\mathrm{HO}_{2}$ and $\mathrm{H}$ radicals play only a minor role ( $<2 \%$ ) (see Fig. $4 \mathrm{~b}$ ). The rate of change of the $\mathrm{CH}_{2} \mathrm{O}$ mixing ratio in the reactor can thus be described as:

$\frac{d\left[\mathrm{CH}_{2} \mathrm{O}\right]}{d t}=-(J+K)\left[\mathrm{CH}_{2} \mathrm{O}\right]$

where $J$ is the sum of photolysis rates of (R1) (i.e., $j_{r}$ ) and (R2) (i.e., $j_{m}$ ) and $K$ is the sum of the products of the relevant 
photochemical reaction rate coefficients $\left(k_{i}\right)$ and radical concentrations $\left(X_{i}\right)$ as follows.

$$
\begin{aligned}
& J=j_{m}+j_{r} \\
& K=\sum_{i} k_{i}\left[X_{i}\right]
\end{aligned}
$$

In the same way, for the next abundant isotopologue, CHDO, one obtains:

$$
\frac{d[\mathrm{CHDO}]}{d t}=-\left(J^{\prime}+K^{\prime}\right)[\mathrm{CHDO}]
$$

where $J^{\prime}$ and $K^{\prime}$ indicate the sums of the photolysis rates and the photochemical reaction rates for CHDO, respectively.

In terms of non-equilibrium kinetics, the isotopic fractionation factor is represented as the kinetic isotope effect (or simply isotope effect), which is expressed by the ratio of reaction rates for the different isotopologues, one of which has a rare isotope substituted for the common one (Melander and Saunders, 1980). We define here the isotopic fractionation factor as the ratio of photochemical reaction rates or photolysis rates of an isotopologue which has a single deuterium to that for the most abundant isotopologue. For instance, the isotopic fractionation factor for the molecular channel, $\alpha_{m}$ is:

$\alpha_{m}=\frac{j_{m}^{\prime}}{j_{m}}$

Hence, $J^{\prime}$ and $K^{\prime}$ in Eq. (4) have the following relationship with the corresponding rates for $\mathrm{CH}_{2} \mathrm{O}$ by means of isotopic fractionation factor, $\alpha_{i}$.

$$
\begin{aligned}
J^{\prime} & =j_{r}^{\prime}+j_{m}^{\prime} \\
& =\alpha_{r} j_{r}+\alpha_{m} j_{m} \\
K^{\prime} & =\sum_{i} k_{i}^{\prime}\left[X_{i}\right] \\
& =\sum_{i} \alpha_{k_{i}} k_{i}\left[X_{i}\right] \\
& =\alpha_{K} K
\end{aligned}
$$

By definition, the isotopic fractionation factor for $\mathrm{CH}_{2} \mathrm{O}$, $\alpha_{f}$, is

$$
\begin{aligned}
\alpha_{f} & =\frac{J^{\prime}+K^{\prime}}{J+K} \\
& =\alpha_{r} \times \frac{j_{r}}{J} \times \frac{J}{J+K}+\alpha_{m} \times \frac{j_{m}}{J} \times \frac{J}{J+K}+\alpha_{K} \times \frac{K}{J+K}
\end{aligned}
$$

In Eq. (8a), the ratio of $j_{m}$ to $J$ represents the yield of $\mathrm{H}_{2}$ from photolysis of $\mathrm{CH}_{2} \mathrm{O}\left(\Phi\left(\mathrm{H}_{2}\right)\right)$, and the ratio $J /(J+K)$ is the fraction of $\mathrm{CH}_{2} \mathrm{O}$ that is photolyzed. Designating the latter as $\Gamma, \alpha_{f}$ can be rewritten as

$\alpha_{f}=\alpha_{r}(1-\Phi) \Gamma+\alpha_{m} \Phi \Gamma+\alpha_{K}(1-\Gamma)$

Or simply,

$\alpha_{f}=\alpha_{h v} \Gamma+\alpha_{K}(1-\Gamma)$ where $\alpha_{h v}$ represents the isotopic fractionation factor for photolysis of $\mathrm{CH}_{2} \mathrm{O}$. Since the amount of radicals produced along the experiments is not constant, $\Gamma$ is not a constant but varies as a function of time. In addition, strictly speaking, $\Phi\left(\mathrm{H}_{2}\right)$ varied during the sunlight experiments as did SZA (Fig. 3b). Accordingly $\alpha_{f}$ is changing along with the $\mathrm{CH}_{2} \mathrm{O}$ photolysis and photochemical reactions. Nevertheless, assuming that $\alpha_{f}$ is constant gives a convenient way to determine the isotopic fractionation factor for the production of $\mathrm{H}_{2}, \alpha_{m}$.

Integrating Eqs. (1) and (4) and then dividing [CHDO] by $\left[\mathrm{CH}_{2} \mathrm{O}\right]$ leads to the well-known Rayleigh equation (Rayleigh, 1902):

$\frac{R_{Q}}{R_{o}}=f^{\alpha_{f}-1}$

where $R_{O}$ is the isotope ratio of the initial $\mathrm{CH}_{2} \mathrm{O}, R_{Q}$ is that for the remaining $\mathrm{CH}_{2} \mathrm{O}$ along the course of experiment, and $f$ the fraction of the remaining $\mathrm{CH}_{2} \mathrm{O}$. Thus, the isotope ratio of the products $\left(R_{p}\right)$ as a function of $\mathrm{CH}_{2} \mathrm{O}$ photochemical destruction can be obtained by mass balance:

$\frac{R_{p}}{R_{o}}=\frac{1-f^{\alpha_{f}}}{1-f}$

Actually $R_{p}$ is the sum of the isotope ratios of the products formed by $\mathrm{CH}_{2} \mathrm{O}$ photolysis and its photochemical reactions with radicals. The isotope ratio of the $\mathrm{H}_{2}, R_{m}$, which is produced from $\mathrm{CH}_{2} \mathrm{O}$ photolysis to the molecular channel, can be derived from the following derivatives:

$\frac{d\left[\mathrm{H}_{2}\right]}{d t}=j_{m}\left[\mathrm{CH}_{2} \mathrm{O}\right]$

and

$\frac{d[\mathrm{HD}]}{d t}=j_{m}^{\prime}[\mathrm{CHDO}]$

Solving Eqs. (11) and (12) with inserting the solutions of Eqs. (1) and (4), respectively, and the definition of $\alpha_{m}$ in Eq. (5), $R_{m}$ has the following relation with $R_{o}$ :

$\frac{R_{m}}{R_{o}}=\frac{\alpha_{m}}{\alpha_{f}} \times \frac{1-f^{\alpha_{f}}}{1-f}$

By dividing (13) by (10), the ratio of the isotope ratios of $\mathrm{H}_{2}$ $\left(R_{m}\right)$ and all products from $\mathrm{CH}_{2} \mathrm{O}$ photochemistry $\left(R_{p}\right)$ is the same as the ratios of their isotopic fractionation factors:

$\frac{R_{m}}{R_{p}}=\frac{\alpha_{m}}{\alpha_{f}}$

Similar experessions can be derived for the radical channel of $\mathrm{CH}_{2} \mathrm{O}$ photolysis (15) and for the photochemical reactions (16):

$\frac{R_{r}}{R_{p}}=\frac{\alpha_{r}}{\alpha_{f}}$ 
Table 2. Sensitivity test of the $\alpha_{r}$ at a given range of the parameters.

\begin{tabular}{|c|c|c|c|c|}
\hline & $\begin{array}{l}\text { Prescribed value } \\
\left(Z_{i}\right)\end{array}$ & $\begin{array}{l}\text { Uncertainty of parameter } \\
\left(\Delta Z_{i}\right)\end{array}$ & $\begin{array}{l}\text { Sensitivity } \\
\left(\Delta \alpha_{r} / \Delta Z_{i}\right)\end{array}$ & $\begin{array}{l}\text { Uncertainty of } \alpha_{r} \\
\left(\Delta \alpha_{r}\right)\end{array}$ \\
\hline$\left[\mathrm{CH}_{2} \mathrm{O}\right]_{0}(\mathrm{ppm})$ & 1 & \pm 1 & $0.0027 *$ & \pm 0.003 \\
\hline$J_{\mathrm{CH}_{2} \mathrm{O}}\left(\mathrm{s}^{-1}\right)$ & $3.143 \times 10^{-5}$ & $\begin{array}{l}+4.53 \times 10^{-5} \\
-3.14 \times 10^{-5}\end{array}$ & $0.0026^{*}$ & \pm 0.004 \\
\hline$\Phi\left(\mathrm{H}_{2}\right)$ & 0.647 & \pm 0.039 & -0.476 & $\mp 0.019$ \\
\hline$J_{\mathrm{H}_{2} \mathrm{O}_{2}} / J_{\mathrm{CH}_{2} \mathrm{O}}$ & 0.0896 & \pm 0.0036 & -2.48 & $\mp 0.009$ \\
\hline$\alpha_{\mathrm{H}}$ for $\mathrm{CH}_{2} \mathrm{O}+\mathrm{H}$ & 0.781 & \pm 0.25 & $\sim 0$ & $\sim 0$ \\
\hline$\alpha_{\mathrm{OH}}$ for $\mathrm{CH}_{2} \mathrm{O}+\mathrm{OH}$ & 0.781 & \pm 0.0061 & -0.45 & $\mp 0.003$ \\
\hline$\alpha_{\mathrm{HO}_{2}}$ for $\mathrm{CH}_{2} \mathrm{O}+\mathrm{HO}_{2}$ & 0.781 & \pm 0.25 & -0.036 & $\mp 0.009$ \\
\hline$\delta \mathrm{D}-\mathrm{H}_{2}$ of final product $(\% o)$ & 0 & \pm 40 & -0.0019 & $\mp 0.076$ \\
\hline Sum** & & & & 0.079 \\
\hline
\end{tabular}

* Sensitivity is calculated by the ratio of a parameter to the prescribed value.

** Quadratic sum of errors.

$\frac{R_{K}}{R_{p}}=\frac{\alpha_{K}}{\alpha_{f}}$

From the relations of Eqs. (14), (15), and (16), it is immediately recognized that $R_{p}$ is the weighted sum of the isotope ratios of the products from two channels of $\mathrm{CH}_{2} \mathrm{O}$ photolysis and its photochemical reactions, similar to the isotopic fractionation factor of $\mathrm{CH}_{2} \mathrm{O}$ in Eq. (8b).

$R_{p}=R_{r}(1-\Phi) \Gamma+R_{m} \Phi \Gamma+R_{K}(1-\Gamma)$

Since we measured the evolution of $R_{m}$ with $\Psi\left(\mathrm{H}_{2}\right), \alpha_{m}$ can be determined from Eq. (13). As $f$ approaches 1 (thus, $\Psi\left(\mathrm{H}_{2}\right)$ goes to zero), $R_{m} / R_{o}$ in Eq. (13) becomes the value of $\alpha_{m}$, which is in turn represented by the value of $\delta \mathrm{D}-\mathrm{H}_{2}$ as follows:

$\delta \mathrm{D}-\mathrm{H}_{2}=\left(\alpha_{m}-1\right) \times 1000(\% \circ)$

Accordingly, the intercept in Fig. $5\left(\Psi\left(\mathrm{H}_{2}\right)=0\right)$ represents the value of $\alpha_{m}(=0.50( \pm 0.02))$ and indicates that $\mathrm{H}_{2}$ produced by photolysis of $\mathrm{CH}_{2} \mathrm{O}$ is $500( \pm 20) \%$ o depleted with respect to the initial $\mathrm{CH}_{2} \mathrm{O}$. Since the experiments for the photolysis of $\mathrm{CH}_{2} \mathrm{O}$ for short periods were conducted with high $\mathrm{CH}_{2} \mathrm{O}$ mixing ratios of $50 \mathrm{ppm}$, a similar amount of initial $\mathrm{CH}_{2} \mathrm{O}$, was applied in the 1-box model to determine the value of $\alpha_{m}$. Its uncertainty, 0.02, was determined such that all measurements for the short periods experiments are predicted by the 1-box model within the range of errors (see Fig. 5). The assumption that $\alpha_{f}$ is constant should be valid during the initial stage of photolysis of $\mathrm{CH}_{2} \mathrm{O}$ because the amounts of radicals, in particular the $\mathrm{OH}$ radical, produced are too small to affect $\alpha_{f}$ (see Fig. 4b). Even if $\alpha_{f}$ were not constant, it would not interfere with the determination of $\alpha_{m}$ because the $\alpha_{f}$ 's in Eq. (13) cancel for $f$ approaching 1.
3.4 Isotope effect of $\mathrm{CH}_{2} \mathrm{O}$ photolysis to the radical channel

Provided that complete photolysis of $\mathrm{CH}_{2} \mathrm{O}$ yields $\mathrm{H}_{2}$ that has the same isotope ratio as that of the initial $\mathrm{CH}_{2} \mathrm{O}$ (Fig. 5), we can also determine the isotopic fractionation factor, $\alpha_{r}$, which governs the isotopic fractionation occurring in (R1). However, in this case the Rayleigh model cannot be applied because the value of $\alpha_{f}$ varies with time due to changes in the amounts of radicals (see below). We ran a photochemical 1-box model instead, which consists of the 33 reactions mentioned in Sect. 3.2 as well as critical reactions of CHDO and HD to determine $\alpha_{r}$ as follows:

$$
\begin{aligned}
& \mathrm{CHDO}+h v \rightarrow \text { products } \\
& \mathrm{CHDO}+h v \rightarrow \mathrm{CO}+\mathrm{HD} \\
& \mathrm{CHDO}+\mathrm{OH} \rightarrow \text { products } \\
& \mathrm{CHDO}+\mathrm{H} \rightarrow \text { products } \\
& \mathrm{CHDO}+\mathrm{HO}_{2} \rightarrow \mathrm{HOCHDOO} \\
& \mathrm{HD}+\mathrm{OH} \rightarrow \text { products } \\
& \mathrm{HOCHDOO} \rightarrow \mathrm{CHDO}^{-\mathrm{HO}_{2}} \\
& \mathrm{HOCHDOO}+\mathrm{HO}_{2} \rightarrow \text { products }
\end{aligned}
$$

In Fig. 5 several model runs under different conditions are plotted. As an ideal case, we assume that $\mathrm{CH}_{2} \mathrm{O}$ is destroyed exclusively by photolysis. Since in this scenario $\alpha_{f}$ is constant as the reaction proceeds, the Rayleigh model can be applied to determine $\alpha_{r}$. In Eq. (13), as $f$ approaches 0, the ratio of $R_{m}$ to $R_{o}$ becomes the ratio of $\alpha_{m}$ to $\alpha_{f}$, which is represented by the value of $\delta \mathrm{D}-\mathrm{H}_{2}$ at the end of photolysis. As the values of $\delta \mathrm{D}-\mathrm{H}_{2}$ converge at zero, $\alpha_{f}=\alpha_{m}$ and thus $\alpha_{m}=\alpha_{r}$ 
Table 3. Comparison of the isotope effects determined from $\mathrm{CH}_{2} \mathrm{O}$ photolysis experiments.

\begin{tabular}{|c|c|c|c|c|c|c|c|c|c|}
\hline Source & $\begin{array}{c}\text { Minor } \\
\text { isotopologue }\end{array}$ & $\alpha_{m}$ & $\alpha_{r}$ & ${ }^{*} \alpha_{\mathrm{OH}}$ & $\Phi\left(\mathrm{H}_{2}\right)$ & $* * \Gamma$ & $\alpha_{h v}$ & $\alpha_{f}$ & $\alpha_{m} / \alpha_{f}$ \\
\hline This study & [CHDO] & $0.50( \pm 0.02)$ & $0.22( \pm 0.08)$ & $0.781( \pm 0.006)$ & $0.65( \pm 0.04)$ & $0.69( \pm 0.28)$ & $0.40( \pm 0.03)$ & $0.51( \pm 0.11)$ & $0.97( \pm 0.21)$ \\
\hline Feilberg et al. (2007b) & [CHDO] & $0.55( \pm 0.02)$ & $0.91( \pm 0.05)$ & $0.781( \pm 0.006)$ & $* * * 0.77( \pm 0.06)$ & $0.69( \pm 0.28)$ & $0.63( \pm 0.01)$ & $0.68( \pm 0.04)$ & $0.81( \pm 0.06)$ \\
\hline Crounse et al. (2003) & [CHDO] & 0.8 & & & & & & & \\
\hline Feilberg et al. (2007a) & {$\left[\mathrm{CD}_{2} \mathrm{O}\right]$} & & & & & & $0.333( \pm 0.056)$ & & \\
\hline
\end{tabular}

* Kinetic isotope effect for $\mathrm{CH}_{2} \mathrm{O}+\mathrm{OH}$ from Feilberg et al. (2004).

** The value is calculated for the Mainz conditions for the periods of experiments.

*** The value was calculated by the relation $\alpha_{h v}=\alpha_{m} \times \Phi\left(\mathrm{H}_{2}\right)+\alpha_{r} \times\left(1-\Phi\left(\mathrm{H}_{2}\right)\right)$.

according to the relation in Eq. (8b) since $\Gamma=1$. This scenario is, however, unlikely considering the substantial production of radicals via the radical channel (R1), which may in turn react with $\mathrm{CH}_{2} \mathrm{O}$ in the reactor as described above. Introduction of the reactions of $\mathrm{H}$ and/or $\mathrm{HO}_{2}$ with both $\mathrm{CH}_{2} \mathrm{O}$ and $\mathrm{CHDO}$ with and without kinetic isotope effect do not significantly change the evolution of $\delta \mathrm{D}-\mathrm{H}_{2}$ compared to the ideal scenario that only accounts for $\mathrm{CH}_{2} \mathrm{O}$ photolysis. However, it is apparent that the reaction of $\mathrm{OH}$ and $\mathrm{CH}_{2} \mathrm{O}$ is critical for determination of $\alpha_{r}$, as the $\delta \mathrm{D}-\mathrm{H}_{2}$ value for the final product of $\mathrm{H}_{2}$ reaches only $\sim-170 \%$ o. Taking the kinetic isotope effect for the reaction of $\mathrm{CH}_{2} \mathrm{O}$ with $\mathrm{OH}$ radicals into account increases the $\delta \mathrm{D}-\mathrm{H}_{2}$ value for the final product a little to $\sim-130 \%$. Applying the kinetic isotope effect for the reaction of HD with $\mathrm{OH}$ does not improve the model to simulate the measurements because of too slow reaction rate of $\mathrm{H}_{2}+\mathrm{OH}$. However, decreasing the value of $\alpha_{r}$ from 0.50 to 0.22 (thus larger isotope effect) makes it possible to reach the $\delta \mathrm{D}-\mathrm{H}_{2}$ value of the final $\mathrm{H}_{2}$ to zero and significantly improves the predicted evolution of $\delta \mathrm{D}-\mathrm{H}_{2}$ compared to the measurements. Therefore, provided that the TUV radiation model and the reaction rates applied in the 1-box model are correct, our best estimate of $\alpha_{r}$ is 0.22 and the total isotopic fractionation factor of $\mathrm{CH}_{2} \mathrm{O}$ due to photolysis $\left(\alpha_{h v}\right)$ results in 0.40 for $\Phi\left(\mathrm{H}_{2}\right)=0.647$, the yield of $\mathrm{H}_{2}$ which is the best estimate from the TUV radiation model for the average conditions of Mainz at the times of the experiments (see Fig. 3).

As the value of $\alpha_{r}$ in the present study is not determined directly by measurement, but is based on model calculations, we conducted sensitivity runs to estimate the uncertainty of $\alpha_{r}$ by varying the values of the various parameters used in the 1-box model. These parameters are the mixing ratio of $\mathrm{CH}_{2} \mathrm{O}$ in the reactor, $\Phi\left(\mathrm{H}_{2}\right)$, photolysis rates of $\mathrm{CH}_{2} \mathrm{O}$ and $\mathrm{H}_{2} \mathrm{O}_{2}$, kinetic isotope effects for the reaction of CHDO with the radicals, and the uncertainty of $\delta \mathrm{D}-\mathrm{H}_{2}$ for the final product (Table 2). Among them $\alpha_{r}$ is the most sensitive to the ratio of the photolysis rate of $\mathrm{H}_{2} \mathrm{O}_{2}$ to that for $\mathrm{CH}_{2} \mathrm{O}$ because large production of $\mathrm{OH}$ by photolysis of $\mathrm{H}_{2} \mathrm{O}_{2}$ leads to the increase of the fraction of $\mathrm{CH}_{2} \mathrm{O}$ that reacts with $\mathrm{OH}$ in the reactor, which in turn lowers the value of $\alpha_{r}$ to compensate for it (see Eq. 8b). The same effect can be caused by the variation of $\alpha_{\mathrm{OH}}$ for $\mathrm{CH}_{2} \mathrm{O}+\mathrm{OH}$ and by $\Phi\left(\mathrm{H}_{2}\right)$. Sensitivity runs for the potential error in the $\delta \mathrm{D}-\mathrm{H}_{2}$ value of the final product shows the largest impact to $\alpha_{r}$ among the parameters because of its large potential error of $40 \%$, which includes the uncertainty of the $\delta \mathrm{D}$ value of the original $\mathrm{CH}_{2} \mathrm{O}(=4 \%$ o). Overall most of the uncertainty for $\alpha_{r}$ originates from the uncertainties in $\Phi\left(\mathrm{H}_{2}\right)$ and the $\delta \mathrm{D}-\mathrm{H}_{2}$ of the final products. The quadratic sum of the errors incurred by these parameters amounts to 0.08 .

\section{Discussions}

\subsection{Comparison with previous research}

To our knowledge three experiments have been done in sunlight to determine the isotopic fractionation factor for formaldehyde photolysis (Table 3): One experiment investigated the isotopic fractionation of $\mathrm{CH}_{2} \mathrm{O}$ itself by measuring time evolution of the amount of isotopologues, $\mathrm{CH}_{2} \mathrm{O}$ and $\mathrm{CD}_{2} \mathrm{O}$ using an optical method (Feilberg et al., 2007a; Feilberg et al., 2005), another experiment examined the same isotopic fractionation but for $\mathrm{CH}_{2} \mathrm{O}$ and $\mathrm{CHDO}$ using the same technique and the $\mathrm{D} / \mathrm{H}$ ratio of $\mathrm{H}_{2}$ produced by mass spectrometry (Feilberg et al., 2007b), and the other measured the $\mathrm{D} / \mathrm{H}$ ratio of $\mathrm{H}_{2}$ produced from the photolysis of $\mathrm{CH}_{2} \mathrm{O}$ which is reported in a conference proceeding abstract (Crounse et al., 2003). In the latter study a similar procedure as in the present study was apparently applied. However, the lack of details of the experiment, in particular the fraction of $\mathrm{H}_{2}\left(\Psi\left(\mathrm{H}_{2}\right)\right)$ and the $\delta \mathrm{D}$ value of the original $\mathrm{CH}_{2} \mathrm{O}$ used for the photolysis experiments, both of which are critical to determine $\alpha_{m}$, makes it difficult to infer $\alpha_{m}$ from this single value of $\delta \mathrm{D}$. The authors reported that the photolysis of $\mathrm{CH}_{2} \mathrm{O}$ produces isotopically light $\mathrm{H}_{2}$, the $\delta \mathrm{D}$ value of which is $\sim-200 \%$. If the authors meant the value to be the degree of enrichment of the $\mathrm{H}_{2}$ produced, $\alpha_{m}$ is $\sim 0.8$, which is far larger (so less isotopically fractionated) than what we obtained in this study.

In the case of Feilberg et al. (2005)'s experiments, the ratio of photolysis rate of the two isotopologues, $J_{\mathrm{CD}_{2} \mathrm{O}} / J_{\mathrm{CH}_{2} \mathrm{O}}$, was determined as $0.333( \pm 0.056)$ (Feilberg et al., 2007a) using an optical technique. This value is smaller than the value for $J_{\mathrm{CHDO}} / J_{\mathrm{CH}_{2} \mathrm{O}}\left(=\alpha_{h v}\right)$ of $0.40( \pm 0.03)$ determined in the present study as expected from the assumption 
that double-deuterated formaldehyde is more stable than the single-deuterated one due to zero point energy difference.

Recent work reported by the same group (Feilberg et al., 2007b) has a particular interest as the goal of the experiment is the same as the present study, but approaches it in a different way. In this experiment, the authors determined the values of $\alpha_{m}$ and $\alpha_{h v}$ as $0.55( \pm 0.02)$ and $0.63( \pm 0.01)$, respectively. The value of $\alpha_{m}$ is similar to, while that for $\alpha_{h v}$ is far larger than, the values determined in the present study. Actually the large discrepancy of $\alpha_{h v}$ points to a much larger difference in the value of $\alpha_{r}$ between Feilberg et al. (2007b) and the present study: $0.91( \pm 0.05)$ versus $0.22( \pm 0.08)$. Unlike the previous work (Feilberg et al., 2005), Feilberg et al. (2007b) took into account the $\mathrm{CH}_{2} \mathrm{O}$ production in the chamber of the facility in determination of $\alpha_{h v}$ in addition to leakage of the experimental chamber. Notwithstanding, there is still such a large discrepancy in the isotopic fractionation factors of $\mathrm{CH}_{2} \mathrm{O}$ between the two studies. Besides the discrepancy in the magnitude of $\alpha_{r}$, an interesting result of Feilberg et al. (2007b) is that the degree of the isotopic fractionation in $\mathrm{CH}_{2} \mathrm{O}$ photolysis to the molecular channel is larger than that for the radical channel, being opposite to the results from the present study and from early results by McQuigg and Calvert (1969).

It is useful to recall the different experimental conditions in both studies. Feilberg et al. (2007b) performed an isotopic tracer study using similar amounts of $\mathrm{CH}_{2} \mathrm{O}$ and $\mathrm{CHDO}$ in the EUPHORE reactor in Valencia, Spain, which allowed them to infer $\alpha_{h v}$ directly by a spectroscopic method. $\alpha_{m}$ was then inferred from the isotope-ratio-mass-spectrometric measurements of $\mathrm{HD}$ and modeling of the $\mathrm{H}_{2}$ yield using a given quantum yield for $\mathrm{CH}_{2} \mathrm{O}$ photolysis. The direct determination of $\alpha_{h v}$ using spectroscopic measurement, however, had to be corrected to account for the losses of $\mathrm{CH}_{2} \mathrm{O}$ and $\mathrm{CHDO}$ by the reaction with $\mathrm{OH}$ radical and large leakage of air in the chamber as well as production of $\mathrm{CH}_{2} \mathrm{O}$ from the wall. In addition, their values of $\alpha_{r}$ and $\alpha_{m}$ depend on which value of the quantum yield for $\mathrm{CH}_{2} \mathrm{O}$ photolysis are applied. In our study, performed at the level of natural deuterium abundance, $\alpha_{m}$ is the "directly" inferred quantity, and $\alpha_{h v}$ follows from the experimental results that the isotopic compositions of the initial $\mathrm{CH}_{2} \mathrm{O}$ and of the $\mathrm{H}_{2}$ that are formed from complete photolysis are virtually the same, but it also requires a correction for reaction with radicals. At present we are not able to identify the reason of the large discrepancy in the isotopic fractionation factors of $\mathrm{CH}_{2} \mathrm{O}$ between the two studies. More experiments can resolve this issue.

\subsection{Atmospheric implication}

The determination of $\alpha_{m}$ and $\alpha_{r}$ may provide an important insight to comprehend what causes the enrichment in D throughout the photochemical oxidation pathway from $\mathrm{CH}_{4}$ to $\mathrm{H}_{2}$. The overall composite of isotopic fractionation factors from $\mathrm{CH}_{4}$ to $\mathrm{H}_{2}, \alpha_{\mathrm{CH}_{4}-\mathrm{H}_{2}}$, may be defined as:

$\alpha_{\mathrm{CH}_{4}-\mathrm{H}_{2}}=\frac{R_{\mathrm{H}_{2}}^{0}}{R_{\mathrm{CH}_{4}}}$

where $R_{\mathrm{H}_{2}}^{0}$ represents the isotope ratio of $\mathrm{H}_{2}$ produced by photochemical oxidation of $\mathrm{CH}_{4}$ and $\mathrm{R}_{\mathrm{CH}_{4}}$ is that for $\mathrm{CH}_{4}$. Strictly speaking, $\alpha_{\mathrm{CH}_{4}-\mathrm{H}_{2}}$ differs from the general definition of isotopic fractionation factor in that it is a function of not only thermodynamic conditions but also environmental parameters such as radiation, radical species and their concentrations in the atmosphere. Nonetheless, given a system with these parameters, $\alpha_{\mathrm{CH}_{4}-\mathrm{H}_{2}}$ can be considered as an isotopic fractionation factor. Rhee et al. (2006a) estimated the value of $\alpha_{\mathrm{CH}_{4}-\mathrm{H}_{2}}$ to be 1.3 in the troposphere, meaning that the $\mathrm{H}_{2}$ produced from $\mathrm{CH}_{4}$ oxidation is enriched in D by 1.3 times as much as the initial $\mathrm{CH}_{4}$. Gerst and Quay (2001) and Price et al. (2007) also expected D in the $\mathrm{H}_{2}$ from photochemical oxidation of $\mathrm{CH}_{4}$ to be enriched by a factor of 1.2-1.3.

As Gerst and Quay (2001) described in detail, $\alpha_{\mathrm{CH}_{4}-\mathrm{H}_{2}}$ is the product of several factors that are associated with photochemical chain reactions from $\mathrm{CH}_{4}$ to $\mathrm{H}_{2}$. These factors include: (1) isotopic fractionation occurring during the reaction of $\mathrm{CH}_{4}$ with $\mathrm{OH}\left(\alpha_{\mathrm{CH}_{4}}\right)$, the rate-determining step of the photochemical chain reactions of $\mathrm{CH}_{4}$, as well as the subsequent isotopic fractionation processes occurring along the way to $\mathrm{CH}_{2} \mathrm{O}\left(\alpha_{\Sigma}\right)$, (2) the branching ratios in the reactions of deuterated species, e.g., $\mathrm{CH}_{3} \mathrm{D}, \mathrm{CH}_{2} \mathrm{DOOH}$, and $\mathrm{CH}_{2} \mathrm{DO}$, (3) the factor of 2 brought up by the reduction of the number of hydrogen atoms from $\mathrm{CH}_{4}$ to $\mathrm{CH}_{2} \mathrm{O}$, and finally (4) isotopic fractionation occurring during the photolytical production of $\mathrm{H}_{2}$ from $\mathrm{CH}_{2} \mathrm{O}$. Assuming that $\mathrm{CH}_{2} \mathrm{O}$ is in a photochemical steady state, as it has a far shorter chemical lifetime than $\mathrm{CH}_{4}$ and $\mathrm{H}_{2}$, point (4) is represented by the ratio of the isotopic fractionation factor of the $\mathrm{H}_{2}$ produced $\left(\alpha_{m}\right)$ to that for $\mathrm{CH}_{2} \mathrm{O}\left(\alpha_{f}\right)$, which determines the degree of $\mathrm{D}$ enrichment of $\mathrm{H}_{2}$ (Rhee et al., 2006a). Note that $\alpha_{f}$ differs from $\alpha_{h v}$ by the effect of isotopic fractionation arising from reaction with $\mathrm{OH}$ radical $\left(\alpha_{\mathrm{OH}}\right)$ in the troposphere. Combining all these factors yields:

$\alpha_{\mathrm{CH}_{4}-\mathrm{H}_{2}}=2 \times \alpha_{\mathrm{CH}_{4}} \times \beta_{\mathrm{CH}_{4}} \times \alpha_{\Sigma} \times \beta_{p} \times \frac{\alpha_{m}}{\alpha_{f}}$

where $\beta_{\mathrm{CH}_{4}}$ is the branching ratio for the deuterated product, $\mathrm{CH}_{2} \mathrm{D}$, in the reaction of $\mathrm{CH}_{3} \mathrm{D}$ and $\mathrm{OH}$, and $\beta_{p}$ is a combined branching ratio for other short-lived intermediates, $\mathrm{CH}_{2} \mathrm{DOOH}$, and $\mathrm{CH}_{2} \mathrm{DO}$.

Regarding the right-hand side of Eq. (20), the value of $\alpha_{\mathrm{CH}_{4}}$ is $0.78( \pm 0.07)$ at $298 \mathrm{~K}$ (Gierczak et al., 1997) and decreases with the decrease of temperature, that for $\beta_{\mathrm{CH}_{4}}$ is at most unity but most likely is less than unity as Gerst and Quay (2001) speculated, and the same is expected for $\beta_{p}$. In the subsequent reactions, there is no compelling rationale that the more deuterated isotopologues react faster than the lighter ones considering the theoretical view of lower 
zero point energy for the isotopically heavier isotopologues. Thus, the value of $\alpha_{\Sigma}$ may not be larger than unity. The last two parameters in Eq. (20), $\alpha_{f}$ and $\alpha_{m}$, are what we are concerned with here: since $\alpha_{f}$ is a combined isotopic fractionation factor due to photolysis and photochemical reactions of $\mathrm{CH}_{2} \mathrm{O}$ by the fraction of the reaction routes as shown in Eqs. (8), the value is the weighted mean of the isotopic fractionation factors involved in the reactions. As listed in Table 3 under the radiation conditions of Mainz, the best values of $\alpha_{m}$ and $\alpha_{r}$ were estimated as $0.50( \pm 0.02)$ and $0.22( \pm 0.08)$, respectively, from the present study. Feilberg et al (2004) determined the value of $\alpha_{\mathrm{OH}}$ as $0.781( \pm 0.006)$. The optimal values of $\Phi\left(\mathrm{H}_{2}\right)$ and $\Gamma$ in Mainz were calculated as $0.647( \pm 0.039)$ and $0.69( \pm 0.28)$, respectively, for the periods of experiments using the TUV radiation model at a weighted mean SZA of $62.7^{\circ}$ (see Fig. 3). In order to determine $\Gamma$, we calculated $\mathrm{OH}$ radical concentrations and their uncertainties from the relationship between the photolysis rate of $\mathrm{O}_{3}\left(\mathrm{~J}\left(\mathrm{O}^{1} \mathrm{D}\right)\right)$ and $\mathrm{OH}$ concentration by Rohrer and Berresheim (2006) (i.e., $[\mathrm{OH}]=2.4 \times J\left(\mathrm{O}^{1} \mathrm{D}\right)+0.13$ and $\left.\sigma=0.07 \times 10^{6}+0.33 \times[\mathrm{OH}]\right)$. By inserting these values into Eq. (8b) the resulting value for $\alpha_{f}$ is $0.51( \pm 0.11)$. Most of its uncertainty is carried over from the uncertainty of $\mathrm{OH}$. The resulting ratio of $\alpha_{m} / \alpha_{f}(=0.97( \pm 0.21))$ is slightly lower than unity, but because of its large uncertainty, arising from the uncertainty of the $\mathrm{OH}$ concentration, it is not possible to predict with certainty whether the $\mathrm{CH}_{2} \mathrm{O}$ photolysis leads to a depletion or enrichment of $\mathrm{D}$ in the $\mathrm{H}_{2}$ produced with respect to the parent $\mathrm{CH}_{2} \mathrm{O}$. When using the values of isotopic fractionation factors determined by Feilberg et al. (2007b), the $\mathrm{CH}_{2} \mathrm{O}$ photolysis leads to the depletion of $\mathrm{D}$ in the $\mathrm{H}_{2}$, however, even taking into account the uncertainty of $\alpha_{m} / \alpha_{f}$ (see Table 3).

We extend the calculation of the ratio of $\alpha_{m} / \alpha_{f}$ to a range of values of $\Phi\left(\mathrm{H}_{2}\right)$ and $\Gamma$, assuming that the values of $\alpha_{m}$, $\alpha_{r}$, and $\alpha_{\mathrm{OH}}$ determined from the present study and Feilberg et al. (2004) are applicable to the entire troposphere. The potential ranges of $\Phi\left(\mathrm{H}_{2}\right)$ for the troposphere were estimated using the TUV radiation model with varying SZA at the altitudes of the US standard atmosphere. In order to estimate $\Gamma$ for the troposphere, it is necessary to know the reaction rate of $\mathrm{CH}_{2} \mathrm{O}+\mathrm{OH}$ at a given time and place. The reaction rate coefficient varies by $\sim 15 \%$ in the troposphere due to change in temperature, while the $\mathrm{OH}$ concentration varies in the order of magnitude with its peak occurring at local noon. The peak values are well above $10^{7}$ molecules $\mathrm{cm}^{-3}$ (e.g., Berresheim et al., 2003), leading to $\Gamma \sim 0.45$. Thus, the range of $\Gamma$ is likely to be between 0.4 and 1 in the troposphere. As shown in Fig. 6, the ratios of $\alpha_{m} / \alpha_{f}$ vary from $\sim 0.8$ to $\sim 1.2$, which suggests that, depending on the values of $\Gamma$ and $\Phi\left(\mathrm{H}_{2}\right)$ in the troposphere, the $\mathrm{H}_{2}$ produced from the $\mathrm{CH}_{2} \mathrm{O}$ photolysis could be either enriched or depleted in D. For instance, at the Earth's surface the values of $\alpha_{m} / \alpha_{f}$ along the track of the sun are likely to be lower than unity, thus yielding the depleted $\mathrm{H}_{2}$ in D with respect to the parent $\mathrm{CH}_{2} \mathrm{O}$.

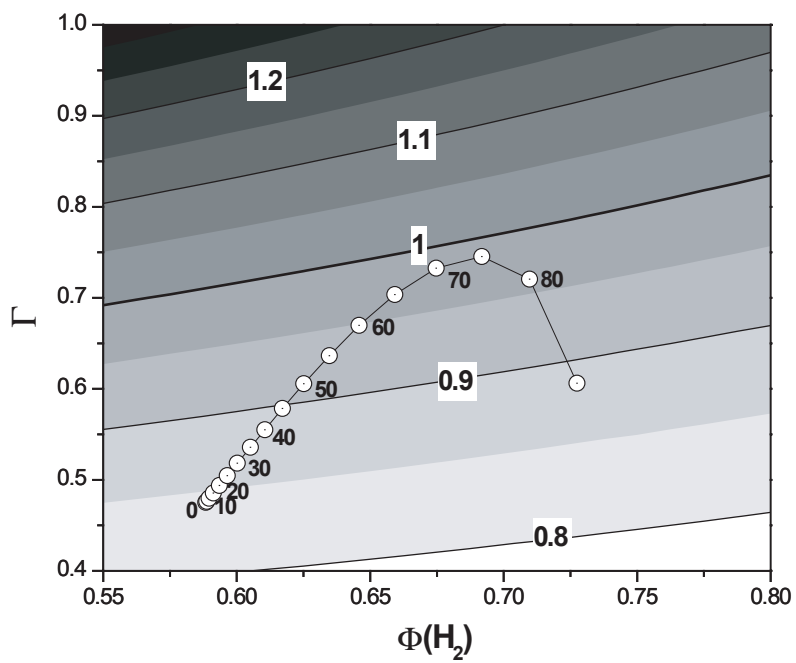

Fig. 6. Contour plot of the ratio $\alpha_{m} / \alpha_{f}$ for potential ranges of the yield of $\mathrm{H}_{2}$ from $\mathrm{CH}_{2} \mathrm{O}$ photolysis $\left(\Phi\left(\mathrm{H}_{2}\right)\right)$ and of the fraction of $\mathrm{CH}_{2} \mathrm{O}$ that is decomposed by photolysis $(\Gamma)$ in the troposphere. The symbols track the values of $\Phi\left(\mathrm{H}_{2}\right)$ and $\Gamma$ calculated by the TUV radiation model and Rohrer and Berresheim (2006)'s parameterization of $\mathrm{OH}$ concentration at the indicated solar zenith angle (SZA) from $0^{\circ}$ to $85^{\circ}$ in $5^{\circ}$ steps at Earth's surface.

Finally, we examine the range of $\alpha_{m} / \alpha_{f}$ that can be reconciled with the values of $\alpha_{\mathrm{CH}_{4}-\mathrm{H}_{2}}$ inferred for tropospheric conditions. In the literature it is reported that $\alpha_{\mathrm{CH}_{4}-\mathrm{H}_{2}}$ would be between 1.2 and 1.3 in the troposphere (Gerst and Quay, 2001; Price et al., 2007; Rhee et al., 2006a). According to Gierczak et al. (1997), the value of $\alpha_{\mathrm{CH}_{4}}$ at the tropospheric mean temperature of $272 \mathrm{~K}$ is $0.77( \pm 0.08)$. Inserting these values into Eq. (20), the lower bound for $\alpha_{m} / \alpha_{f}$ will be $\sim 0.8$ when the branching ratio for deuterated compounds $\left(\beta_{\mathrm{CH}_{4}}\right.$ and $\left.\beta_{p}\right)$ and $\alpha_{\Sigma}$ are unity. When the values proposed by Gerst and Quay (2001) are applied (i.e., $\left.\beta_{\mathrm{CH}_{4}} \times \alpha_{\Sigma} \times \beta_{p}=0.96 \times 0.77 \times 0.96\right), \alpha_{m} / \alpha_{f}$ is 1.15 . These two values of $\alpha_{m} / \alpha_{f}$ bound the range which was estimated for the typical values of $\Gamma$ and $\Phi\left(\mathrm{H}_{2}\right)$ in the troposphere (Fig. 6). This suggests that even if $\alpha_{m} / \alpha_{f}$ is smaller than unity it is still possible that $\mathrm{H}_{2}$ formed from the photochemical oxidation of $\mathrm{CH}_{4}$ is enriched in D with respect to the original $\mathrm{CH}_{4}$ due to the factor of 2 that arises from the reduction of the number of hydrogen atom. Recent laboratory experiment (Nilsson et al., 2007) reports the branching ratio for $\mathrm{CH}_{2} \mathrm{DO}$ reacting with $\mathrm{O}_{2}$ to be $0.88( \pm 0.01)$, suggesting $\beta_{p}$ to be lower than unity and that $\alpha_{m} / \alpha_{f}$ is likely to be larger than unity.

\section{Conclusions}

$\mathrm{CH}_{2} \mathrm{O}$ photolysis experiments conducted in sunlight under ambient conditions allowed us to determine the isotopic fractionation factors for both the radical (R1) and molecular (R2) channels. The $\mathrm{H}_{2}$ produced is depleted in D by $500( \pm 20) \%$ o with respect to the initial $\mathrm{CH}_{2} \mathrm{O}$. The radical channel (R1) 
appears to have a much stronger isotopic fractionation than the molecular channel (R2), resulting in D enrichment of the remaining $\mathrm{CH}_{2} \mathrm{O}$ by $780( \pm 80) \%$. This isotope effect is significantly larger than the result obtained from the experiments in the EUPHORE reaction chamber by Feilberg et al. (2007b), a difference we do not understand at present.

Applying the isotopic fractionation factors obtained from the present study to the conditions of Mainz, $\mathrm{CH}_{2} \mathrm{O}$ photolysis may produce the $\mathrm{H}_{2}$ that is slightly depleted in D. However, the large uncertainty in the combined isotope effects of the photochemical reactions of $\mathrm{CH}_{2} \mathrm{O}$, which primarily originates from the uncertainty of $\mathrm{OH}$ concentration, makes it impossible to precisely define the role of $\mathrm{CH}_{2} \mathrm{O}$ photolysis in the $\mathrm{D}$ enrichment of $\mathrm{H}_{2}$. In the troposphere, $\mathrm{CH}_{2} \mathrm{O}$ photolysis may produce the $\mathrm{H}_{2}$ either enriched or depleted in $\mathrm{D}$ with respect to the parent $\mathrm{CH}_{2} \mathrm{O}$ depending on the fraction of $\mathrm{CH}_{2} \mathrm{O}$ that reacts with $\mathrm{OH}$ or that is photolyzed to $\mathrm{H}_{2}$. Nonetheless, our estimated range of $\alpha_{m} / \alpha_{f}(\sim 0.8$ to $\sim 1.2)$ in the troposphere can be reconciled with the production of $\mathrm{H}_{2}$ enriched in $\mathrm{D}$ with respect to the original $\mathrm{CH}_{4}$ by the factor reported in the literature.

Table A1. Photochemical reactions in the model.

\section{Appendix A}

\section{1-box photochemistry model}

The 1-box model is composed of 33 reactions (Table A1) running at $25^{\circ} \mathrm{C}$ and $10^{5} \mathrm{~Pa}$ of air which is composed of $78 \%$ of $\mathrm{N}_{2}$ and $22 \%$ of $\mathrm{O}_{2}$. Unless otherwise mentioned, the yield of $\mathrm{H}_{2}$ in the photolysis of $\mathrm{CH}_{2} \mathrm{O}$ and the ratio of $J_{\mathrm{H}_{2} \mathrm{O}_{2}} / J_{\mathrm{CH}_{2} \mathrm{O}}$ are assumed to be 0.647 and 0.0896 , respectively, following the result from the TUV radiation model in Mainz.

Acknowledgements. We gratefully acknowledge support of this research from the Max Planck Society. We thank J. Crowley for advice concerning photochemistry and his suggestion to conduct a simple experiment and K. Boering for useful comments to the earlier version. T. S. R. thanks Korea Meteorological Administration Research and Development Program under Grant CATER 20074405 and Korea Polar Research Program under Grant PE08030 for research support.

Edited by: J. N. Crowley

\begin{tabular}{|c|c|c|c|}
\hline No.* & Reaction & Rate coefficient ${ }^{* *}$ & Notes \\
\hline (R1) & $\mathrm{CH}_{2} \mathrm{O}+h v \rightarrow \mathrm{CHO}+\mathrm{H}$ & $1.109 \mathrm{E}-5$ & 1 \\
\hline (R2) & $\mathrm{CH}_{2} \mathrm{O}+h v \rightarrow \mathrm{CO}+\mathrm{H}_{2}$ & $2.033 \mathrm{E}-5$ & 1 \\
\hline (R3) & $\mathrm{CH}_{2} \mathrm{O}+\mathrm{OH} \rightarrow \mathrm{CHO}+\mathrm{H}_{2} \mathrm{O}$ & $8.6 \mathrm{E}-12 \times \exp (166 / R T)$ & 2 \\
\hline (R3') & $\mathrm{CH}_{2} \mathrm{O}+\mathrm{OH} \rightarrow \mathrm{HCOOH}+\mathrm{H}$ & $2.01 \mathrm{E}-13$ & 9 \\
\hline (R4) & $\mathrm{CH}_{2} \mathrm{O}+\mathrm{H} \rightarrow \mathrm{CHO}+\mathrm{H}_{2}$ & $2.14 \mathrm{E}-12 \times \exp (-9063 / R T) \times(\mathrm{T} / 298)^{1.62}$ & 8 \\
\hline (R5) & $\mathrm{CH}_{2} \mathrm{O}+\mathrm{HO}_{2} \rightarrow \mathrm{HOCH}_{2} \mathrm{OO}$ & $6.71 \mathrm{E}-15 \times \exp (4989 / R T)$ & 3 \\
\hline (R6) & $\mathrm{H}_{2}+\mathrm{OH} \rightarrow \mathrm{H}+\mathrm{H}_{2} \mathrm{O}$ & $5.5 \mathrm{E}-12 \times \exp (-16629 / R T)$ & 3 \\
\hline (R7) & $\mathrm{H}_{2} \mathrm{O}_{2}+h v \rightarrow 2 \mathrm{OH}$ & $2.816 \mathrm{E}-6$ & 1 \\
\hline (R8) & $\mathrm{O}_{2}+\mathrm{CHO} \rightarrow \mathrm{CO}+\mathrm{HO}_{2}$ & $3.5 \mathrm{E}-12 \times \exp (1164 / R T)$ & 3 \\
\hline (R9) & $\mathrm{CHO}+\mathrm{CHO} \rightarrow \mathrm{CH}_{2} \mathrm{O}+\mathrm{CO}$ & $5.0 \mathrm{E}-11$ & 4 \\
\hline (R9') & $\mathrm{CHO}+\mathrm{CHO} \rightarrow(\mathrm{CHO})_{2}$ & $5.0 \mathrm{E}-11$ & 5 \\
\hline (R10) & $\mathrm{CHO}+\mathrm{H} \rightarrow \mathrm{CO}+\mathrm{H}_{2}$ & $1.13 \mathrm{E}-10$ & 6 \\
\hline (R11) & $\mathrm{CHO}+\mathrm{OH} \rightarrow \mathrm{CO}+\mathrm{H}_{2} \mathrm{O}$ & $1.69 \mathrm{E}-10$ & 4 \\
\hline (R12) & $\mathrm{CHO}+\mathrm{HO}_{2} \rightarrow$ product & $5.0 \mathrm{E}-11$ & 4 \\
\hline (R13) & $\mathrm{H}_{2} \mathrm{O}+\mathrm{CHO} \rightarrow \mathrm{CH}_{2} \mathrm{O}+\mathrm{OH}$ & $8.54 \mathrm{E}-13 \times \exp (-108920 / R T)$ & 7 \\
\hline (R14) & $\mathrm{H}_{2} \mathrm{O}_{2}+\mathrm{CHO} \rightarrow \mathrm{CH}_{2} \mathrm{O}+\mathrm{HO}_{2}$ & $1.69 \mathrm{E}-13 \times \exp (-29018 / R T)$ & 7 \\
\hline (R15) & $\mathrm{O}_{2}+\mathrm{H} \rightarrow \mathrm{HO}_{2}$ & $M \times 5.71 \mathrm{E}-32 \times(\mathrm{T} / 298)^{-1.6}$ & 3 \\
\hline (R16) & $\mathrm{H}+\mathrm{H} \rightarrow \mathrm{H}_{2}$ & $M \times 8.85 \mathrm{E}-33 \times(\mathrm{T} / 298)^{-0.6}$ & 4 \\
\hline (R17) & $\mathrm{OH}+\mathrm{H} \rightarrow \mathrm{H}_{2} \mathrm{O}$ & $M \times 4.38 \mathrm{E}-30 \times(\mathrm{T} / 298)^{-2.0}$ & 4 \\
\hline (R18) & $(\mathrm{CHO})_{2}+\mathrm{OH} \rightarrow$ product & $1.1 \mathrm{E}-11$ & 2 \\
\hline (R19) & $\mathrm{HCOOH}+\mathrm{OH} \rightarrow$ product & 4.0E-13 & 3 \\
\hline (R20) & $\mathrm{CO}+\mathrm{OH} \rightarrow \mathrm{CO}_{2}+\mathrm{H}$ & $1.5 \mathrm{E}-13 \times(1+0.6 \times \mathrm{P} / 1013.25)$ & 3 \\
\hline (R21) & $\mathrm{CO}+\mathrm{HO}_{2} \rightarrow \mathrm{CO}_{2}+\mathrm{OH}$ & $5.96 \mathrm{E}-11 \times \exp (-95616 / R T) \times(\mathrm{T} / 298)^{0.5}$ & 10 \\
\hline (R22) & $\mathrm{OH}+\mathrm{OH} \rightarrow \mathrm{H}_{2} \mathrm{O}_{2}$ & $M \times 6.20 \mathrm{E}-31 \times(\mathrm{T} / 298)^{-1}$ & 3 \\
\hline (R23) & $\mathrm{HO}_{2}+\mathrm{H} \rightarrow$ product & $8.10 \mathrm{E}-11$ & 3 \\
\hline (R24) & $\mathrm{HO}_{2}+\mathrm{OH} \rightarrow \mathrm{H}_{2} \mathrm{O}+\mathrm{O}_{2}$ & $4.8 \mathrm{E}-11 \times \exp (2079 / R T)$ & 3 \\
\hline (R25) & $\mathrm{HO}_{2}+\mathrm{HO}_{2} \rightarrow \mathrm{H}_{2} \mathrm{O}_{2}+\mathrm{O}_{2}$ & $M \times 1.7 \mathrm{E}-33 \times \exp (8314 / R T)$ & 3 \\
\hline (R26) & $\mathrm{H}_{2} \mathrm{O}_{2}+\mathrm{OH} \rightarrow \mathrm{HO}_{2}+\mathrm{H}_{2} \mathrm{O}$ & $2.91 \mathrm{E}-12 \times \exp (-1330 / R T)$ & 3 \\
\hline (R27) & $\mathrm{HOCH}_{2} \mathrm{OO} \rightarrow \mathrm{HO}_{2}+\mathrm{CH}_{2} \mathrm{O}$ & $2.4 \mathrm{E} 12 \times \exp (-58201 / R T)$ & 2 \\
\hline (R28) & $\mathrm{HOCH}_{2} \mathrm{OO}+\mathrm{HO}_{2} \rightarrow \mathrm{HCOOH}+\mathrm{H}_{2} \mathrm{O}+\mathrm{O}_{2}$ & $5.6 \mathrm{E}-15 \times \exp (19123 / R T)$ & 2 \\
\hline (R29) & $2 \mathrm{HOCH}_{2} \mathrm{OO} \rightarrow 2 \mathrm{HOCH}_{2} \mathrm{O}+\mathrm{O}_{2}$ & $5.5 \mathrm{E}-12$ & 11 \\
\hline (R29') & $2 \mathrm{HOCH}_{2} \mathrm{OO} \rightarrow \mathrm{HCOOH}+\mathrm{CH}_{2}(\mathrm{OH})_{2}+\mathrm{O}_{2}$ & $5.71 \mathrm{E}-14 \times \exp (6236 / R T)$ & 11 \\
\hline (R30) & $\mathrm{O}_{2}+\mathrm{HOCH}_{2} \mathrm{O} \rightarrow \mathrm{HCOOH}+\mathrm{HO}_{2}$ & $3.5 \mathrm{E}-14$ & 12 \\
\hline
\end{tabular}

Notes: 1. TUV radiation model; 2. Atkinson et al. (1997); 3. DeMore et al. (1997); 4. Baulch et al. (1992); 5. Stoeckel et al. (1985); 6. Ziemer et al. (1998); 7. Tang and Hampson (1986); 8. Baulch et al. (1994); 9. Yetter et al. (1989); 10. Volman (1996); 11. Atkinson et al. (1992); 12. Veyret et al. (1982)

* Prime (') designates the second reaction.

** $R$ and $T$ in rate constant designate gas constant and absolute temperature, respectively. $M$ indicates air concentration in termolecular reaction. The units of the rate coefficients for first-, second-, and third-order reactions are $\mathrm{s}^{-1}, \mathrm{~cm}^{3}$ molecule $\mathrm{e}^{-1} \mathrm{~s}^{-1}$, and $\mathrm{cm}^{6}$ molecule ${ }^{-2} \mathrm{~s}^{-1}$, respectively. 


\section{References}

Atkinson, R., Baulch, D. L., Cox, R. A., Hampson Jr., R. F., Kerr, J. A., Rossi, M. J., and Troe, J.: Evaluated kinetic, photochemical and heterogeneous data for atmospheric chemistry: supplement V, IUPAC subcommittee on gas kinetic data evaluation for atmospheric chemistry, J. Phys. Chem. Ref. Data, 26, 521-1011, 1997.

Atkinson, R., Baulch, D. L., Cox, R. A., Hampsonm Jr., R. F., Kerr, J. A., and Troe, J.: Evaluated kinetic and photochemical data for atmospheric chemistry: Supplement IV. IUPAC subcommittee on gas kinetic data evaluation for atmospheric chemistry, J. Phys. Chem. Ref. Data, 21(6), 1125-1568, 1992.

Baulch, D. L., Cobos, C. J., Cox, R. A., Esser, C., Frank, P., Just, T., Kerr, J. A., Pilling, M. J., Troe, J., Walker, R. W., and Warnatz, J.: Evaluated kinetic data for combustion modelling, J. Phys. Chem. Ref. Data, 21(3), 411-734, 1992.

Baulch, D. L., Cobos, C. J., Cox, R. A., Frank, P., Hayman, G., Just, T., Kerr, J. A., Murrells, T., Pilling, M. J., Troe, J., Walker, R. W., and Warnatz, J.: Evaluated kinetic data for combustion modelling. Supplement I., J. Phys. Chem. Ref. Data, 23, 847-1033, 1994.

Berresheim, H., Plass-Dulmer, C., Elste, T., Mihalopoulos, N., and Rohrer, F.: $\mathrm{OH}$ in the coastal boundary layer of Crete during MINOS: Measurements and relationship with ozone photolysis, Atmos. Chem. Phys., 3, 639-649, 2003, http://www.atmos-chem-phys.net/3/639/2003/.

Burrows, J. P., Moortgat, G. K., Tyndall, G. S., Cox, R. A., Jenkin, M. E., Hayman, G. D., and Veyret, B.: Kinetics and mechanism of the photooxidation of formaldehyde. 2. Molecular modulation studies, J. Phys. Chem., 93(6), 2375-2382, 1989.

Calvert, J. G.: The homogeneous chemistry of formaldehyde generation and destruction within the atmosphere, in: Proceedings of the NATO advanced study institute on Atmospheric Ozone: Its variation and human influences, edited by: Aikin, A. C. and Nicholet, M., 153-190, 1980.

Carlier, P., Hannachi, H., and Mouvier, G.: The Chemistry of Carbonyl-Compounds in the Atmosphere - a Review, Atmos. Environ., 20(11), 2079-2099, 1986.

Crounse, J. D., Rahn, T., Wennberg, P. O., and Eiler, J.: Isotopic composition of molecular hydrogen formed from the photolysis of formaldehyde in sunlight, EOS Transactions, 84(36), F178, 2003.

DeMore, W. B., Sander, S. P., Golden, D. M., Hampson, R. F., Kurylo, M. J., Howard, C. J., Ravishankara, A. R., Kolb, C. E., and Molina, M. J.: Chemical kinetics and photochemical data for use in stratospheric modeling, Jet Propulsion Laboratory, JPL Publication 94-4, Pasadena, California, 269 pp., 1997.

Feilberg, K. L., D’Anna, B., Johnson, M. S., and Nielsen, C.: Additions and Corrections: Relative tropospheric photolysis rates of $\mathrm{HCHO}, \mathrm{H}^{13} \mathrm{CHO}, \mathrm{HCH}^{18} \mathrm{O}$, and DCDO measured at the European Photoreactor facility, J. Phys. Chem. A, 111(5), p. 992, 2007a.

Feilberg, K. L., D’Anna, B., Johnson, M. S., and Nielsen, C. J.: Relative tropospheric photolysis rates of $\mathrm{HCHO}, \mathrm{H}^{13} \mathrm{CHO}$, $\mathrm{HCH}^{18} \mathrm{O}$, and DCDO measured at the European Photoreactor facility, J. Phys. Chem., 109(37), 8314-8319, 2005.

Feilberg, K. L., Johnson, M. S., Bacak, A., Röckmann, T., and Nielsen, C. J.: Relative tropospheric photolysis rates of HCHO and HCDO measured at the European Phtotoreactor facility, J.
Phys. Chem., 111(37), 9034-9046, 2007b.

Feilberg, K. L., Johnson, M. S., and Nielsen, C. J.: Relative reaction rates of $\mathrm{HCHO}, \mathrm{HCDO}, \mathrm{DCDO}, \mathrm{H}^{13} \mathrm{CHO}$, and $\mathrm{HCH}^{18} \mathrm{O}$ with $\mathrm{OH}, \mathrm{Cl}, \mathrm{Br}$, and $\mathrm{NO}_{3}$ radicals, J. Phys. Chem., 108(36), 7393-7398, 2004.

Finlayson-Pitts, B. J. and Pitts Jr., J. N.: Chemistry of the upper and lower atmoshere, Academic Press, San Diego, 1999.

Frost, G. J., Fried, A., Lee, Y.-N., Wert, B., Henry, B., Drummond, J. R., Evans, M. J., Fehsenfeld, F. C., Goldan, P. D., Holloway, J. S., Hubler, G., Jakoubek, R., Jobson, B. T., Knapp, K., Kuster, W. C., Roberts, J., Rudolph, J., Ryerson, T. B., Stohl, A., Stroud, C., Sueper, D. T., Trainer, M., and Williams, J.: Comparisons of box model calculations and measurements of formaldehyde from the 1997 North Atlantic Regional Experiment, J. Geophys. Res., 107(D8), doi:10.1029/2001JD000896, 2002.

Garcia, A. R., Volkamer, R., Molina, L. T., Molina, M. J., Samuelson, J., Mellqvist, J., Galle, B., Herndon, S. C., and Kolb, C. E.: Separation of emitted and photochemical formaldehyde in Mexico City using a statistical analysis and a new pair of gas-phase tracers, Atmos. Chem. Phys., 6, 4545-4557, 2006, http://www.atmos-chem-phys.net/6/4545/2006/.

Gerst, S. and Quay, P.: Deuterium component of the global molecular hydrogen cycle, J. Geophys. Res., 106(D5), 5021-5031, 2001.

Gierczak, T., Talukdar, R. K., Herndon, S. C., Vaghjiani, G. L., and Ravishankara, A. R.: Rate coefficients for the reactions of hydroxyl radicals with methane and deuterated methanes, J. Phys. Chem., 101(17), 3125-3134, 1997.

Horowitz, A. and Calvert, J. C.: The quantum efficiency of the primary processes in formaldehyde photolysis at $3130 \AA$ and $25^{\circ} \mathrm{C}$, Int. J. Chem. Kinet., 10, 713-732, 1978.

Martin, R. V., Parrish, D. D., Ryerson, T. B., Nicks Jr., D. K., Chance, K., Kurosu, T. P., Jacob, D. J., Sturges, E. D., Fried, A., and Wert, B. P.: Evaluation of GOME satellite measurements of tropospheric $\mathrm{NO}_{2}$ and $\mathrm{HCHO}$ using regional data from aircraft campaigns in the southeastern United States, J. Geophys. Res., 109, D24307, doi:10.1029/2004JD004869, 2004.

McQuigg, RD., and Calvert, JG.: The photodecomposition of $\mathrm{CH}_{2} \mathrm{O}, \mathrm{CD}_{2} \mathrm{O}, \mathrm{CHDO}$, and $\mathrm{CH}_{2} \mathrm{O}-\mathrm{CD}_{2} \mathrm{O}$ mixtures at xenon flash lamp intensities, J. Am. Chem. Soc., 91(7), 1590-1599, 1969.

Melander, L. and Saunders Jr., W. H.: Reaction rates of isotopic molecules, John Wiley \& Sons, New York, 391 pp., 1980.

Meller, R. and Moortgat, G. K.: Temperature dependence of the absorption cross sections of formaldehyde between 223 and $323 \mathrm{~K}$ in the wavelength range $225-375 \mathrm{~nm}$, J. Geophys. Res., 105(D6), 7089-7101, 2000.

Moore, C. B. and Weisshaar, J. C.: Formaldehyde photochemistry, Annu. Rev. Phys. Chem., 34, 525-555, 1983.

Moortgat, G. K., Seiler, W., and Warneck, P.: Photodissociation of $\mathrm{HCHO}$ in air : $\mathrm{CO}$ and $\mathrm{H}_{2}$ quantum yields at 220 and $300 \mathrm{~K}, \mathrm{~J}$. Chem. Phys., 78(3), 1185-1190, 1983.

Nilsson, E. J. K., Johnson, M. S., Taketani, F., Matsumi, Y., Hurley, M. D., and Wallington, T. J.: Atmospheric deuterium fractionation: $\mathrm{HCHO}$ and $\mathrm{HCDO}$ yields in the $\mathrm{CH} 2 \mathrm{DO}+\mathrm{O} 2$ reaction, Atmos. Chem. Phys., 7, 5873-5881, 2007, http://www.atmos-chem-phys.net/7/5873/2007/.

Novelli, P. C., Lang, P. M., Masarie, K. A., Hurst, D. F., Myers, R., and Elkins, J. W.: Molecular hydrogen in the troposphere: 
Global distribution and budget, J. Geophys. Res., 104(D23), 30 427-30 444, 1999.

Price, H., Jaegle, L., Rice, A., Quay, P., Novelli, P. C., and Gammon, R.: Global budget of molecular hydrogen and its deuterium content: Constraints from ground station, cruise, and aircraft observations, J. Geophys. Res., 112, D22108, doi:10.1029/2006JD008152, 2007.

Rahn, T., Eiler, J. M., Boering, K. A., Wennberg, P. O., McCarthy, M. C., Tyler, S., Schauffler, S., Donnelly, S., and Atlas, E.: Extreme deuterium enrichment in stratospheric hydrogen and the global atmospheric budget of $\mathrm{H}_{2}$, Nature, 424, 918-921, 2003.

Rayleigh, L.: On the distillation of binary mixtures, Philos. Mag., 4(23), 521-537, 1902.

Rhee, T. S., Brenninkmeijer, C. A. M., Braß, M., and Brühl, C.: The isotopic composition of $\mathrm{H}_{2}$ from $\mathrm{CH}_{4}$ oxidation in the stratosphere and the troposphere, J. Geophys. Res., 111, D23303, doi:10.1029/2005JD6760, 2006a.

Rhee, T. S., Brenninkmeijer, C. A. M., and Röckmann, T.: The overwhelming role of soils in the global atmospheric hydrogen cycle, Atmos. Chem. Phys., 6, 1611-1625, 2006b.

Rhee, T. S., Mak, J., Röckmann, T., and Brenninkmeijer, C. A. M.: Continuous-flow isotope analysis of the deuterium/hydrogen ratio in atmospheric hydrogen, Rapid Commun. Mass Spectrom., 18(3), 299-306, 2004.

Röckmann, T., Rhee, T. S., and Engel, A.: Heavy hydrogen in the stratosphere, Atmos. Chem. Phys., 3, 2015-2023, 2003, http://www.atmos-chem-phys.net/3/2015/2003/.

Rohrer, F. and Berresheim, H.: Strong correlation between levels of tropospheric hydroxyl radicals and solar ultraviolet radiation, Nature, 442, 184-187, 2006.

Sander, S. P., Friedl, R. R., Ravishankara, A. R., Golden, D. M., Kolb, C. E., Kurylo, M. J., Molina, M. J., Moortgat, G. K., Keller-Rudek, H., Finlayson-Pitts, B. J., Wine, P. H., Huie, R. E., and Orkin, V. L.: Chemical Kinetics and Photochemical Data for Use in Atmospheric Studies: Evaluation number 15, Jep Propulsion Laboratory, JPL Publication 06-2, Pasadena, CA, 2006.

Spence, R. and Wild, W.: The preparation of liquid monomeric formaldehyde, J. Chem. Soc., 338-340, 1935.

Stoeckel, F., Schuh, M. D., Goldstein, N., and Atkinson, G. H.: Time-resolved intracavity laser spectroscopy: $266 \mathrm{~nm}$ photodissociation of acetaldehyde vapor to form HCO, Chem. Phys., 95, 135-144, 1985.

Su, F., Calvert, J. G., and Shaw, J. H.: Mechanism of the photooxidation of gaseous formaldehyde, J. Phys. Chem., 83(25), 31853191, 1979.

Tang, W. and Hampson, R. F.: Chemical kinetic data base for com- bustion chemistry. Part I. Methane and related compounds, J. Phys. Chem. Ref. Data, 15, 1087-1279, 1986.

Townsend, D., Lahankar, S. A., Lee, S. K., Chambreau, S. D., Suits, A. G., Zhang, X., Rheinecker, J., Harding, L. B., and Bowman, J. M.: The roaming atom: Straying from the reaction path in formaldehyde decomposition, Science, 306(5699), 1158-1161, 2004.

Troe, J.: Analysis of quantum yields for the photolysis of formaldehyde at lambda $>310 \mathrm{~nm}$, J. Phys. Chem. A, 111(19), 38683874, 2007.

Veyret, B., Lesclaux, R., Rayez, M. T., Rayez, J. C., Cox, R. A., and Moortgat, G. K.: Kinetics and mechanism of the photooxidation of formaldehyde. 1. Flash photolysis study, J. Phys. Chem., 93(6), 2368-2374, 1989.

Veyret, B., Rayez, J. C., and Lesclaux, R.: Mechanism of the photooxidation of formaldehyde studied by flash photolysis of $\mathrm{CH}_{2} \mathrm{O}-\mathrm{O}_{2}-\mathrm{NO}$ mixtures, J. Phys. Chem., 86, 3424-3430, 1982.

Volman, D. H.: Photochemistry of the gaseous hydrogen peroxidecarbon monoxide system IV. Survey of the rate constant and reaction profile for the $\mathrm{HO}_{2}+\mathrm{CO} \rightarrow \mathrm{CO}_{2}+\mathrm{OH}$ reaction, J. Photochem. Photobiol., A, 100(1), 1-3, 1996.

Wagner, V., von Glasow, R., Fischer, H., and Crutzen, P. J.: Are $\mathrm{CH}_{2} \mathrm{O}$ measurements in the marine boundary layer suitable for testing the current understanding of $\mathrm{CH}_{4}$ photooxidation? : A model study, J. Geophys. Res., 107(D3), 4029, doi:10.1029/2001JD000722, 2002.

Warneck, P.: Chemistry of the natural atmosphere, Academic Press, San Diego, 927 pp., 1999.

Weller, R., Schrems, O., Boddenberg, A., Gab, S., and Gautrois, M.: Meridional distribution of hydroperoxides and formaldehyde in the marine boundary layer of the Atlantic $\left(48^{\circ} \mathrm{N}-35^{\circ} \mathrm{S}\right)$ measured during the Albatross campaign, J. Geophys. Res., 105(D11), 14 401-14412, 2000.

Wittrock, F., Richter, A., Oetjen, H., Burrows, J. P., Kanakidou, M., Myriokefalitakis, S., Volkamer, R., Beirle, S., Platt, U., and Wagner, T.: Simultaneous global observations of glyoxal and formaldehyde from space, Geophys. Res. Lett., 33(16), L16804, doi:10.1029/2006GL026310, 2006.

Yetter, R. A., Rabitz, H., Dryer, F. L., Maki, R. G., and Klemm, R. B.: Evaluation of the rate constant for the reaction $\mathrm{OH}+\mathrm{H}_{2} \mathrm{CO}$ : Application of modeling and sensitivity analysis techniques for determination of the product branching ratio, J. Chem. Phys., 91(7), 4088-4097, 1989.

Ziemer, H., Dobe, S., Wagner, H.G., Olzmann, M., Viskolcz, B., and Temp, F.: Kinetics of the reactions of $\mathrm{HCO}$ with $\mathrm{H}$ and D atoms, Ber. Bunsen-Ges. Phys. Chem., 102, 897-905, 1998. 